This document is the accepted manuscript version of the following article:

Burga, C. A., Krüsi, B., Egli, M., Wern1i, M., Elsener, S., Ziefle, M., ... Mavris, C. (2010). Plant succession and soil development on the foreland of the Morteratsch glacier (Pontresina, Switzerland): straight forward or chaotic? Flora, 205(9), 561-576.

https://doi.org/10.1016/j.flora.2009.10.001

\title{
Plant succession and soil development on the foreland of the Morteratsch glacier (Pontresina, Switzerland): Straight forward or chaotic?
}

Conradin A. Burga ${ }^{1}$, Bertil Krüsi ${ }^{2}$, Markus Egli ${ }^{1}$, Michael Wernli $^{2}$, Stefan Elsener ${ }^{3}$, Michael Ziefle $^{3}$, Thomas Fischer ${ }^{1}$ and Christian Mavris ${ }^{1}$

\footnotetext{
${ }^{1}$ Department of Geography University of Zurich, Winterthurerstrasse 190, $\mathrm{CH}-8057$ Zurich

${ }^{2}$ Zürich University of Applied Sciences ZHAW, CH-8820 Wädenswil, Switzerland

${ }^{3}$ Swiss Federal Research Institute WSL, CH-8903 Birmensdorf, Switzerland and Department of Geography University of Zurich, Winterthurerstrasse 190, CH-8057 Zurich, Switzerland
}

\section{Abstract}

As study area we selected the glacier foreland of Morteratsch (approx. 1900 - 2100 m a.s.I.) near Pontresina northwest of the Bernina pass, Upper Engadine, Grisons (Switzerland). The aim of this study is a multimethodological approach using floristic inventories, vegetation an soil mapping of the pro-glacial area, also the detection of crucial parameters of plant resettlement in recently deglaciated areas related to time, local microtopography and soil development.

The following methodological approaches were included in this study: (i) floristic relevees along a chronosequence covering 134 years (1857-1990); (ii) dendrochronological data on tree establishment, collected on a grid with a mesh width of $40 \mathrm{~m}$ in the area, which became ice-free between 1857 and 1980; (iii) vegetation mapping; (iv) soil analyses including physical and chemical properties of 11 typical profiles; (v) soil mapping and (vi) data evaluation using GIS.

Retreating glaciers successively expose mineral substrates that are colonised within a few years by vascular plants, mosses, lichens and soil biota. With increasing plant cover, also the abundance of soil 
organic matter increases. At first sight, the large-scale patterns of vegetation and soil seem to be driven by the time since deglaciation, whereas the small scale patterns may appear chaotic since they depend on local site conditions, which may change dramatically over short distances.

The large-scale pattern seems to develop as follows. About seven years after deglaciation the first pioneer plants establish themselves and form after an additional 20 years the Epilobietum fleischeri community, which today dominate the recently deglaciated areas but may be found in patches more or less on the whole pro-glacial area. By contrast, the first elements of the short living Oxyrietum digynae community appear after approximately 10 years after deglaciation and persist for only about 30 years. Dendrochronology showed that the first European larch and Swiss stone pine trees established themselves 15 and 31 years, respectively, after deglaciation. Surprisingly, on the study area, Swiss stone pine is about twice as frequent as the typical pioneer species European larch (88 vs. 45 stems per ha), despite the fact that larch starts earlier and grows faster than Swiss stone pine (annual height increment: 21 vs. $8 \mathrm{~cm}$ ). Up-to-now, however, nowhere in the 150 year old glacier foreland a near-tomature larch-Swiss stone pine forest can be found.

Besides large-scale factors such as time since deglaciation, topography and disturbance (floods, rockfalls, avalanches), also small-scale factors such as grain size and water content of the substrate, micro-relief and micro-climate seem to be crucial for the development of both vegetation and soil., Time since deglaciation and a straight forward single-pathway succession model are clearly not sufficient for understanding the small-scale patterns of succession. A non-linear succession model with different starting points and different "pathways" of potential primary successions for the different ecological niches is more promising for describing accurately the spatio-temporal vegetation dynamics of the pro-glacial area of Morteratsch.

Keywords: glacier foreland, primary plant succession, soil development, grain size, Upper Engadine, Swiss Alps 
Nomenclatures: Frahm and Frey (1983), Lauber and Wagner (2007), Wirth (1995), Braun-Blanquet (1948), Delarze and Gonseth (2008), Runge (1994)

\section{Introduction}

Since approx. $1850 \mathrm{AD}$, most Alpine glaciers show phases of marked recessions, temporarily interrupted by smaller glacier advances (cf. e.g. Kinzl, 1932; Röthlisberger, 1986; Patzelt, 1985; Burga, 1987; Zumbühl and Holzhauser, 1988; Furrer, 1991; Maisch, 1992; Holzhauser and Zumbühl, 1996). Locally, large deglaciated surfaces arose where vegetation development, i.e. primary plant succession, may be investigated. Where accurate data of glacier movements are available, soil development and vegetation dynamics along time-gradients (chronosequences) and/or using permanent plots can be studied (e.g. Aletsch, Grindelwald, Rhone, Morteratsch, Roseg, Sesvenna glaciers). First investigations on this topic in Swiss and Austrian Alps have been published e.g. by Coaz (1887), von Klebelsberg (1913), Lüdi (1921, 1934) and Oechslin (1935). Mainly Lüdi (1945, 1950, 1955, 1958) studied vegetation development of Swiss glacier forelands (Aletsch, Gries, Hüfi, Grindelwald, Rhone, Morteratsch, Roseg). Friedel $(1938,1956)$ made similar investigations in the Austrian Alps (Hintereisferner, Pasterze). Later studies of Alpine glacier forelands have been done by e.g. Jochimsen (1963), Richard (1973, 1987), Bäumler (1988), Schubiger (1988), Gafner and Hess (1994), Burga (1999), Fischer (1999), Münch (2001), Schwarz (2001), Caccianiga et al. (2001), Rehberger (2002), Treter et al. (2002), Wellstein et al. (2003), Bianchi (2005), Raffl et al. (2006), Krüsi et al. (2007) and others.

Similar investigations of vegetation dynamics were also carried out in other European areas like e.g. Norway (see e.g. Burrows, 1990; Matthews, 1992) and North America, notably in Alaska (e.g. Cooper, 1923 and others, see references in Burrows, 1990 and Stuart et al., 1994), in other parts of the USA (e.g. Jones and Moral, 2005) and in Canada (e.g. Jones and Henry, 2003). In Glacier Bay (Alaska), 
Cooper (1923) established in 1916 the first permanent plots to monitor vegetation development following deglaciation.

Investigations (field experiments) on seed rain, soil seed bank, germination and establishment of seedlings of pioneer plants growing on Swiss Alpine glacier forelands have been carried out e.g. by Fossati (1980), Urbanska and Schütz (1986), Bäumler (1988), Stöcklin and Favre (1994), Stöcklin and Bäumler (1996), Erschbamer et al. (2001) and Marcante et al. (2009). There are also monitoring field experiments on glacier foreland vegetation related to global change (e.g. Erschbamer, 1997, 2007). Phytosociological approaches of primary plant colonisation of Swiss alpine glacier forelands have been used e.g. by Richard (1973, 1987), Bäumler (1988) and Schubiger (1988).

Generally, two main approaches have been used for the study of primary plant succession on glacier forelands, viz. (i) permanent plots and (ii) chronosequences ('space-for-time-substitution'). Local site conditions are crucial for establishing first plant settlers. In most cases, grain size and moisture of the substrate are crucial parameters of plant establishment. A multimethodological approach using vegetation data, soil data and a spatial analysis is however missing in most cases.

According to Landolt (2003) the glacier foreland Morteratsch lies within the Swiss supra-subalpine coniferous belt (European larch-Swiss stone pine forest), its colonisation by larch (Larix decidua) and Swiss stone pine (Pinus cembra) is a part of the primary plant succession processes. At this elevation in the Central Swiss Alps, larch is considered to be the typical pioneer on raw soils, whereas Swiss stone pine is generally believed to require more developed soils. Consequently, we expect larch to dominate the only recently deglaciated areas and stone pine the more advanced successional stages with more developed soils. Contrary to expectations, however, Bianchi (2005) and Elsener (2006) showed that the glacier foreland of Morteratsch is today dominated by Swiss stone pine due to a zoochorous spread by the bird Nucifraga caryocatactes (Mattes, 1982, 1988; Holtmeier, 1993; Kratochwil and Schwabe, 1994).

Using dendrochronology, also Bleuler (1986) investigated germination dates of larch trees on the glacier foreland Morteratsch in relation to the historical glacier extensions. He distinguished three subpopulations, which started their growth $10,10-20$ and 20-30 years, respectively, after deglaciation. On 
undisturbed and otherwise favourable micro-sites, larch can rapidly colonise recently deglaciated areas. Both Bianchi (2005) and Fischer (1999) compared the most advanced successional stages on the glacier foreland of Morteratsch with near-to-undisturbed forests in its immediate surroundings and concluded that 150 years are definitely not sufficient for the formation of mature larch-stone pine forest (Larici-Pinetum cembrae) with a well developed shrub and herb layer.

Plant succession is tightly bound to the underlying substrate and other site factors. Anderson et al. (2000), Matthews and Whittaker (1987), for instance, showed that factor complexes like snow melt, exposure, moisture, terrain and time control vegetation succession. However, only few studies deal with substrate characteristics (parent material) in pro-glacial areas and little is known about the rates of physical and chemical changes of soils in such areas and their consequences for plant growth. Arn (2002), Egli et al. (2003) or Hosein et al. (2004) measured high rates of mineral formation, transformation and chemical denudation, especially on young surfaces, indicating rapid soil development in proglacial areas. In order to explain primary plant succession on glacier forelandsmany authors suggested, therefore, a micro-site approach, taking small-scale differences in microclimate, disturbance levels, water supply, grain size of the substrate and soil development into account (e.g. Gafner \& Hess 1994, Burga (1999 a,b), Böhmer 1999, Elsener 2006, Ziefle 2006, Wüthrich 2008).

The present study aims at elucidating the crucial factors governing plant establishment on recently deglaciated areas such as time since deglaciation, micro-relief or soil development, using a multimethod approach including (i) floristic relevees along a chronosequence covering 134 years (18571990); (ii) dendrochronological data on tree establishment collected using a grid with a mesh width of 40m in the area which became ice-free between 1857 and 1980; (iii) vegetation (iv) soil analyses; (v) soil mapping and (vi) spatial analyses using a GIS. Related to our main question "Straight forward or chaotic?" we try to establish a generalised model explaining the patterns of primary plant succession observed on the glacier foreland Morteratsch. 


\section{Study area}

The investigation area consists of the glacier foreland Morteratsch (approx. 1900 - 2100 m a.s.l.) near Pontresina northwest of the Bernina pass, Upper Engadine, Grisons (Switzerland) (fig. 1, photo 1). The backwall of the glacier is formed by high mountain peaks of the South Raetian Alps like Piz Bernina (4048.6 m asl, the highest peak of the Grisons and the Eastern Alps) and Piz Palü (3901 m asl). The glacier foreland is easily accessible by a trail beginning at the railway station Morteratsch. The area between Pontresina and Morteratsch belongs to the Lower Austroalpine Bernina Nappe s.I. and comprises mainly various plutonic rock types, like granodiorites and alkali-granites, further syenites, diorites and gabbros (Staub 1946, Rageth 1984, Büchi 1987 and 1994, Spillmann 1993).

Palaeo-glaciological and palaeo-ecological studies near the Bernina pass and in the Upper Engadine region were been done by Beeler (1977), Gamper and Suter (1982), Heitz et al. (1982), Kleiber (1974), Punchakunnel (1983), Fitze (1984), Burga (1987), Burga and Perret (1998) and Zoller et al.

(1998). The Swiss Glaciological Commission of the Swiss Academy of Natural Sciences scnat (Gletscherberichte 1881-2008) recorded historical and recent glacier length fluctuations (fig. 2). Rübel published 1912 the first detailed monograph to the plant geography of the Bernina pass area. Herzog (1912) described already the moss flora of the glacier forelands of Morteratsch and Roseg.

The first detailed vegetation map (scale 1:10’000) of the glacier foreland Morteratsch was established by Bäumler (1988). A slightly generalised map on a smaller scale (1:13’700) of the actual vegetation cover (modified and completed after Fischer, 1999) gives an overview to the vegetation pattern of the glacier foreland (fig. 1).

Soils in the pro-glacial area are weakly developed and have a maximum age of 150 years. Forested areas outside the glacier stage of 1857 are characterised by Podzols having an age of 10000 years or more.

\section{Methods}


For the present study, we used a multi-method approach combining (i) floristic relevees along a chronosequence covering 134 years (1857-1990); (ii) dendrochronological data on tree establishment collected usin a grid with a mesh width of $40 \mathrm{~m}$ in the area, which became ice-free between 1857 and 1980; (iii) vegetation; (iv) soil analyses including physical and chemical properties of 11 typical soil profiles; (v) soil mapping and (vi) spatial analyses using a GIS.

\subsection{Vegetation}

Burga established in 199910 permanent plots within the glacier foreland to monitor the vegetation dynamics of deglaciated areas (fig. 1, Burga, 1999a, b). With the help of the vegetation cover of permanent plots and the time since ice retreat (chronosequence 1857-1990), a generalised model of primary plant succession could be established (figs. 3 - 4). A clear correlation between vegetation and grain size of the substrate on consolidated sites could be shown (Burga, 1999a, b). Less obvious is the correlation between plant establishment and the age of the sites (time since deglaciation) due to the great small-scale heterogeneity of factors such as erosion and other disturbances, micro-relief, soil moisture, microclimate etc.

In 2004, a grid with a mesh width of $40 \mathrm{~m}$ was established with the help of the Swiss Federal Research Institute WSL, Birmensdorf, consisting of a total of 464 grid points and covering most of the glacier foreland between the stages 1857 and 1980 (fig. 2). At each grid point, 21 site and vegetation parameters were recorded. By superimposing a deglaciation map (data based on the

Gletscherberichte 1881-2008 and Burga, 1999a,b), the year of deglaciation was assigned to each grid point. On circular plots with a radius of $1 \mathrm{~m}, 2 \mathrm{~m}$ and $5 \mathrm{~m}$ respectively, vegetation and site parameters of the herb, shrub and tree layers were recorded (unpublished data of Elsener, 2006). Using the closest-individual method (Greig-Smith 1983), individuals of larch and Swiss stone pine that were at least $10 \mathrm{~cm}$ tall were sampled at each grid point the closest, measuring the distance to the grid point, tree height, basal stem diameter, tree age and vitality (Elsener, 2006).

At 110 of the grid points, Ziefle (2006, unpublished data) studied the establishment of herbaceous plants and shrubs (mainly willows [Salix spec.]). For this, Ziefle (2006) subdivided the glacier foreland 
into nine deglaciation and two flooding strata viz. ice free since (1) 1986-1995, (2) 1976-1985, (3) 1966-1975, (4) 1956-1965, (5) 1946-1955, (6) 1936-1945, (7) 1926-1935, (8) 1916-1925 and (9) 18571915), flooded in (10) 1955 and (11) 1987, respectively (fig. 2). In each stratum, ten of the established grid points were selected randomly. At each of the selected grid points, age and size of the closest individuals of Salix myrsinifolia and S. helvetica were measured.

As a control study, Bianchi (2005, unpublished data) investigated the establishment of Swiss stone pine and larch in the area outside of the actual pro-glacial area of the Morteratsch glacier, i.e. close to the end moraine of the 1857 stage, located at the edge of the grid mentioned above.

\subsection{Soils}

\subsubsection{Soil mapping}

Soil mapping (scale $1: 10000$ ) within the pro-glacial area was carried out based on aerial photographs and field investigations. Soil cartography and classification were performed according to the FAL system (Brunner et al., 1997). Soil mapping already includes a certain generalisation as small-scale variations (approx. $<100 \mathrm{~m}^{2}$ ) could not be considered (Egli et al. 2006).

Based on the soil (Egli and Kneisel, unpubl.) and vegetation (Bäumler, 1988; Burga, 1999a; Fischer, 1999) maps, spatio-temporal soil and vegetation properties could be compared, both qualitatively and quantitatively. Area calculations (proportions of different soil and vegetation types between two deglaciation isochrones) were performed using ArcGIS 9.3 (ESRI) with modules programmed in Visual Basic for Applications (VBA). Input data sets were the digital soil and vegetation maps, data on historical glacier extensions (Burga, 1999 a,b) and the digital elevation model (20 m grid) within the pro-glacial area.

\subsubsection{Soil analyses}


11 pits were excavated for chemical and physical analyses of the soil material. 10 of them were located next to the permanent vegetation monitoring plots of Burga (1999 a,b). About two to four kilograms of soil material were collected per soil horizon, and the following parameters were measured: organic $\mathrm{C}$ and $\mathrm{N}, \mathrm{pH}$, granulometry, skeleton content, bulk density. At four sites (two Skeletic Leptosols and two Humi-Skeletic Leptosols), water tension (water potential) was monitored during 5 periods within one summer. The water potential was measured at a depth of $0-10 \mathrm{~cm}$ using two to three tensiometers at each site (Jet Fill Tensiometer, Eijkelkamp).

Total $\mathrm{C}$ and $\mathrm{N}$ contents of both the soil and the parent material were measured with a $\mathrm{C} / \mathrm{H} / \mathrm{N}$ analyzer (Elementar Vario EL). Soil pH (in $0.01 \mathrm{M} \mathrm{CaCl}_{2}$ ) was determined on air-dried fine earth samples using a soil to solution ratio of $1: 2.5$.

Particle size distribution was determined on some selected soil samples. After a pre-treatment of the samples with $\mathrm{H}_{2} \mathrm{O}_{2}(3 \%)$, particle size distribution was determined by sieving the coarser particles $(2000-32 \mu \mathrm{m})$ and measuring the finer particles $(<32 \mu \mathrm{m})$ with help of an X-ray-sedimentometer (SediGraph 5100/micromeritics/Germany).

\section{Results}

Primary plant succession of the pro-glacial area of Morteratsch with its predominantly siliceous parent material starts with the pioneer plant communities Oxyrietum digynae (photo 2) and Epilobietum fleischeri (photo 3; Lüdi, 1958; Braun-Blanquet, 1973; Bäumler, 1988; Burga, 1999a,b) and ends with the larch-Swiss stone pine forest (so-called climax vegetation; photo 4) after substantially more than 150 years. The investigations of Burga (1999a, b), based on ten permanent plots covering the chronosequence from about 1857 to 1990, give a general picture of plant succession on the glacier foreland and stress the crucial role of the grain size of the substrate .(figs. $\mathbf{3}$ and $\mathbf{4}$, Burga, 1999a). The following results are based on the vegetation and soil data, collected on a systematic grid, as well as on the detailed vegetation and soil maps (ArcGIS, fig. 5). 


\subsection{Primary plant succession}

\subsubsection{Large-scale pattern}

The first plants, i.e. Epilobium fleischeri, Oxyria digyna, Linaria alpina, Saxifraga aizoides, Rumex scutatus, appear about 7 years after deglaciation and reach greater cover-abundance values after about 27 years (fig. 3). Together they form the long-living Epilobietum fleischeri plant community, which dominates the recently deglaciated areas but of which fragments can be found almost everywhere on the foreland of the Morteratsch glacier (figs. 1, 5, 7). The first species of the short living Oxyrietum digynae appears approx. 10 years after deglaciation and disappears approx. 30 years later (figs. $\mathbf{3}, \mathbf{5}, \mathbf{7}$ ). In the two above-mentioned pioneer communities, frequently also the following plant species can be found: Achillea moschata, Adenostyles leucophylla, Cardamine resedifolia, Cerastium uniflorum, C. pedunculatum, Geum reptans, Myricaria germanica, Poa nemoralis, Poa alpina, Saxifraga bryoides, S. paniculata, Trifolium pallescens and the moss species Pohlia spec. and Rhacomitrium canescens. Moss cushions of Rhacomitrium canescens form the subassociation Epilobietum fleischeri rhacomitrietosum (Braun-Blanquet, 1973). The first small larch trees, the first shrubs of willows and green alder and the first dwarf-shrubs as e.g. the rust-leaved alpenrose are found on areas, which have been ice-free for about 12 to 15 years (figs. 3, 4). Surprisingly, lichens such as Stereocaulon cf. dactylophyllum need about 15-20 years to establish the first populations, and 150 years are definitely not sufficient for the establishment of a larch-Swiss stone pine stand (LariciPinetum cembrae) (figs. 4, 5).

Fig. 7 shows the development after deglaciation of the frequency of occurrence of the more important vegetation types, as shown on the vegetation map fig. 1. Data on the development of the cover of the more important species are given in figs. 3 and 4). Fig. 7 clearly shows the dominant role of the Epilobietum fleischeri pioneer community during the first 100 years of succession. The second most important community is the green alder community, which starts early and grows continually in importance until it overtakes the Epilobietum fleischeri after about the 100 first years of succession. Until about 55 years after deglaciation, pioneer grass communities (Poa nemoralis, $P$. 
alpina, $P$. laxa) develop like green alder but later they decrease, probably due to the increasing shrub cover. Grass heath communities on moister soils are far less frequent and occur only about 60 years after deglaciation.

The first members of the larch-Swiss stone pine climax community establish themselves already 5-10 years after the glacier retreat, but their importance remains low during the first 120 years of succession, and the tree growth is very slow. Approx. 40 years after deglaciation, the first open clusters of small larch and Swiss stone pine trees form. As already mentioned above, the establishment of more or less mature larch-Swiss stone pine forest requires more than 150 years.

\subsubsection{Small-scale pattern in the herb layer}

On areas, which have been ice-free for 10-19 years, Ziefle (2006, unpublished data) found an average of 11.5 plant species (vascular plants, bryophytes, lichens) per $3.14 \mathrm{~m}^{2}$, i.e. on a circular plot with a radius of $1 \mathrm{~m}$. Surprisingly, the small-scale floristic diversity differs only little among the ten strata distinguished along the chronosequence. In contrast to the small-scale floristic diversity, the largescale diversity, as expressed by the cumulative species number on 10 of the above-mentioned plots of $3.14 \mathrm{~m}^{2}$ each, doubled along the chronosequence as expected from 34 species on the youngest to 63 on the oldest stratum (ice-free for 90-150 years). Ziefle (2006, unpublished data) found the following species most often: Rhacomitrium canescens (frequency: 69\%/ cover: $7.6 \%$ ), Poa nemoralis (68\%/ 3.9\%), Epilobium fleischeri (73\%/ 1.7\%), Stereocaulon spec. (38\%/ 2.7\%), Agrostis schraderiana (28\%/ 3.4\%), Achillea moschata (55\%/ 1.5\%), Hieracium staticifolium (60/ 1.2\%), Rumex scutatus (42\%/ 1.1\%), Poa alpina (58\%/ 1.1\%) and Trifolium pallescens (40\%/ 1.0\%).

Multivariate analyses revealed that the 110 vegetation surveys of the herb layer may be grouped into ten vegetation units, each characterised by one dominant or few co-dominant species: (1) Oxyria digyna, (2) Rhacomitrium canescens, (3) Saxifraga spec., (4) Poa alpina/ P. nemoralis, (5) Festuca rubra s.I., (6) Agrostis schraderiana, (7) Adenostyles leucophylla, (8) Stereocaulon spec., (9) Achillea moschata/ Sempervivum spec. and (10) Rhododendron ferrugineum. 
Time since glacier retreat and thus a linear succession model are not sufficient to explain the pattern formed by the above-mentioned vegetation units. In addition to time since deglaciation also micro-site conditions (e.g. grain size of the substrate and water supply) seem to play a crucial role.

Consequently, a micro-site controlled succession model with several different starting points and converging pathways meeting at a common climax seems to describe best the situation observed in the pro-glacial area of Morteratsch (fig. 8).

\subsubsection{Colonisation by larch and Swiss stone pine}

In the foreland of the Morteratsch glacier, surprisingly, Swiss stone pines are twice as frequent as European larch trees ( 88 vs. 45 stems per ha), this despite the fact that larch trees were found to establish themselves much earlier (fig. 4) after glacier retreat than Swiss stone pines (15 vs. 30 years) and to grow much faster (mean annual height increment: 21 vs. $8 \mathrm{~cm}$ ) (Elsener 2006, unpublished data). Today, the pioneer species larch prevails over Swiss stone pine only in the height class above $4 \mathrm{~m}$ (7 vs. 1 stems per ha). Given the actual predominance of Swiss stone pine in all the other height classes, the relative importance of the shade-tolerant Swiss stone pine will likely further increase in the future. In the long-term, saplings of the light-demanding larch will only be able to establish successfully on areas subject to disturbances resulting e.g. from avalanches, flooding or local die-back of Swiss stone pines due to diseases or old age. The successionally most advanced larch-stone pine clusters on the pro-glacial area differ distinctly from close-to-climax stands just outside the glacier stage of 1857 . The larch-stone pine clusters consist by 8 stems per ha within the pro-glacial area and by 416 stems per ha outside of the pro-glacial area, i.e. a ratio of $8 / 416$ stems per ha (fig. $\mathbf{5}$, Bianchi, 2005, unpublished data). A second surprise is the fact, that "time since ice retreat" explains only a comparatively small part of the observed variances in tree height and stem number. The zoochorous Swiss stone pine, considered as typical shade-tolerant climax species mainly germinating on raw humus, is already today much more frequent in the glacier foreland than the anemochorous and lightdemanding larch, germinating on undeveloped raw soils. 


\subsection{Soil development}

The longer a surface is exposed to weathering, the more developed are usually the soils. Although the extent of soil development greatly varies on the pro-glacial area, the above-mentioned general trend could be found and measured. The main soil types are Endoskeletic Fluvisols, Skeletic or Lithic Leptosols, Humi-skeletic Leptosols, including some sites with Ranker (FAO-Unesco, 1998; FAO, 1998) that have a weak B horizon and Dystric and Gleyic Cambisols (endoskeletic) and sites without soil (fig. 5). The youngest soils near today's edge of the glacier show almost no signs of chemical weathering and alteration products. They are usually characterised by a very thin and often discontinuous humus layer. The soils are in general skeleton-rich (defined as the fraction $>2 \mathrm{~mm}$ ). The fine earth of the soils has a high sand content (usually between 50 and 90\%) and partially contains some silt (eolian attribution, grinding due to fluvial transport?). The Fluvisols partially show slightly increased silt content. In all other soils, granulometry is rather uniform. A significant trend of soil physical characteristics with time could be measured: The younger the soils, the greater the skeleton and sand contents (tab. 2, fig. 6a). The decrease in grain size with exposure time is a concomitant effect of weathering. Due to the high proportion of skeleton in the soil, the water content remains low $(<30$ vol.- $\%)$ in all soils. In general, water permeability of all soils is very high. Two different types of soil water regimes could be discerned: (1) soils drying out relatively quickly (tab. 3) and (2) soils remaining moist during the whole summer period due to north-exposure, concave topographical situation or water supply from subsurface flow (see our micro-site primary succession model, fig. 7). The 'dry' soils loose relatively quickly the gravitational water $(<100 \mathrm{hPa})$, which locally may limit plant growth substantially.

Due to the increasing vegetation cover and plant productivity with time since deglaciation, increasingly more organic carbon is transferred into the soils; consequently, the older the soils, the greater the abundance of soil organic matter (fig. 6b). After about 150 years of soil formation, the soil organic matter stock reaches around $1.5-5 \mathrm{~kg} \mathrm{~m}^{-2}$, which is quite considerable. In alpine environments, soils originating from siliceous parent material may contain more than $40 \mathrm{~kg}$ organic $\mathrm{C} \mathrm{m}^{-2}$ (see also Hitz, 
2002) while the C-content of soils on calcareous parent material is often distinctly lower $(15-20 \mathrm{~kg} \mathrm{C}$ $\mathrm{m}^{-2}$; Egli et al., 2008).

Mean annual rates of organic $\mathrm{C}$ accumulation during 150 years of soil development are in the range of $10-33 \mathrm{~g} \mathrm{C} / \mathrm{m}^{2} / \mathrm{y}$. These values are high compared to rates reported from other Holocene chronosequences (Egli et al., 2001: $6.7-9 \mathrm{~g} \mathrm{C} / \mathrm{m}^{2} / \mathrm{y}$ for soils older than 400 years; Lichter, $1998: 9 \mathrm{~g}$ $\mathrm{C} / \mathrm{m}^{2} / \mathrm{y}$ ). In Podzols of the Swiss Alps, the long-term accumulation rates (i.e. approx. 10000 years) are in the range of $2-4 \mathrm{~g} \mathrm{C} / \mathrm{m}^{2} / \mathrm{y}$ (Egli et al., 2001).

\subsection{Relationships between vegetation and soil data}

Comparison of the vegetation and the soil maps (fig. 5) shows similar general succession patterns. There is a good agreement between the vegetation types green alder/ willow scrub/ pioneer grass communities and the occurrence of Humi-Skeletic Leptosols. This vegetation/ soil pattern related to recessional moraines reflects partly some historical glacier stages (figs. 1, 5). The Oxyrietum digynae settles on Skeletic/ Lithic Leptosols or on "no soil" substrate after approx. 10 years after ice retreat and disappears approx. 30 years later (fig. 5, tab. 5). The distribution pattern of the Epilobietum fleischeri with single willow shrubs matches fairly well the distribution of the Skeletic/Lithic Leptosols, which are very poor in nutrient and dry out both quickly and frequently (tabs. 3, 5). The pioneer community Oxyrietum digynae grows preferentially on sites without soil. Undeveloped soils and scarce vegetation is also found on sites repeatedly flooded by the Morteratsch torrent (fig. 2). Likewise nearly free of vegetation and soil are the glacially moulded rock mounds (roche moutonnée). But nevertheless, the following plant species can be found on rock crevasses: e.g. Sempervivum arachnoideum, Agrostis rupestris, Silene rupestris, Veronica fruticans, and also Pinus cembra. On areas covered by mediumsized boulders, however, pockets with fine soil material exist where species grow, as for instance Adenostyles leucophylla, Rumex scutatus, Dryopteris filix-mas, Athyrium filix-femina, and Gymnocarpium dryopteris. Gleyic Cambisols are found in mire micro-biotopes and small ponds (figs. 5, 8). On the NE boundary of the older pro-glacial area (glacier stages 1878-1920) and close to the stage of 1980 Endoskeletic Fluvisols developed due to the floods of 1955 and 1987 (fig. 2). These 
soils with slightly greater contents of carbon and water content are primarily occupied by green alder and willow shrubs. Open larch-Swiss stone pine stands with fairly dense herb layer occur on Dystric Cambisols (tab. 4).In general, concomitant with plant cover also soil organic matter increases. A fast increase in soil organic carbon in young soils within a few decades was also described by Conen et al. (2007), Egli et al. (2002) and in an early study of Jenny (1980).

In conclusion, time since glacier retreat, extent of soil development, grain size distribution of the substrate and local water supply seem to be the principal drivers of vegetation development and, therefore, the basis for a simple, mechanistic, non-linear plant succession model. A more detailed comparison between the occurrence of vegetation units and plant species, on the one hand, and soil data, on the other hand, is given in tabs. 4, 5 and $\mathbf{6}$. The Oxyrietum digynae occurs only on sites having a strongly gravely substrate. Also the Epilobietum fleischeri predominantly grows on sites rich in gravels and stones. Also pioneer grass communities can be recorded at sites with a high gravel or stone occurrence, although they grow also at sites with smaller grain sizes. Grass heath prefers sites with a lower stone and gravel content. The green alder scrub can be mostly found at periodically moist stony sites (tab. 6). According to the expectances, rock vegetation is found at sites that are strongly stony or rocky. In local pockets, rock vegetation grows on a substrate that has a much lower grain size (i.e. silt and clay).

On the whole, local site conditions are highly variable, and the linear primary succession models proposed by Lüdi (1958), Braun-Blanquet (1973) and Bäumler (1988) are not sufficient for explaining accurately the complex spatio-temporal vegetation dynamics of the pro-glacial area of Morteratsch. For this,

a better succession model with several different starting points and the larch-Swiss stone-pine community as common climax is needed (fig. 8).

\section{Discussion and conclusion}


Retreating glaciers successively expose mineral substrates that are colonised within a few years by vascular plants, mosses, lichens and soil biota. Soil development proceeds quickly in the pro-glacial area. 150 years of soil development lead to Ranker (Humi-Skeletic Leptosols) followed by Dystric Cambisol. On the pro-glacial area Morteratsch, we observed significant soil-forming processes such as alteration of parent material, formation of weathering products and accumulation of organic matter (weak B-horizons in Ranker). The rate of soil formation in the Morteratsch area is in the same order of magnitude as reported by other authors (e.g. Haugland, 2004). Fitze (1982) and Patzelt (1973) described Rankers that have been formed in the time span of 200 - 350 years after deglaciation. In Central Alpine areas, Dystric Cambisols usually form within 250 - 300 years after glacier retreat (Egli et al., 2001), whereas Podzols require a minimum duration of about 1200 years (Egli et al., 2003). In general, a fairly good agreement between the spatial patterns of soil types and vegetation units was found.

At first sight, the small-scale vegetation pattern of the pro-glacial area seems to be chaotic. At larger scales, patterns and processes seem clearer (chrono- and topo-sequences, regarding Morteratsch; see Bäumler, 1988; Burga, 1999a; Krüsi et al., 2007). Bäumler (1988) and Burga (1999a) established a rather linear succession model starting with one initial stage, followed by different development pathways and ending with coniferous forest as climax of the subalpine forest belt. In the present paper we propose a more complex succession model with different, micro-sitedependent starting points and one climax stage, i.e. the larch-Swiss stone pine community (fig. 8). This model is quite elegant and accurate but it has also its weaknesses. For instance, some plant species reflect the grain size of soils, soil moisture or other characteristics of substrate (Rhacomitrium canescens and Pohlia spec. patches: clay, silt; Adenostyles leucophylla stands; coarse boulders; Agrostis rupestris and Sempervivum spec. patches; mainly rock surfaces). On the other hand, the model includes different types of micro-sites where primary successions in pro-glacial sections can start (fig. 8). Oxyria digyna is only dominant at initial stages and builds up the typical short-living pioneer plant community Oxyrietum digynae. Epilobietum fleischeri is a wide-spreading and long-lived 
plant community of primary plant succession on glacier forelands dispersed across most of the chrono-sequence (e.g. Lüdi, 1958; Braun-Blanquet, 1973; Bäumler, 1988; Burga, 1999a).

Regarding the growth of larch and Swiss stone pine, the latter tree species is roughly twice as numerous as larch (Elsener, 2006, unpublished data), even though larch is a typical pioneer tree starting earlier after deglaciation and growing faster than Swiss stone pine on ice-free areas of the glacier foreland (Krüsi et al. 2007). This rather unusual situation in the pro-glacial area of Morteratsch may be explained by the local dominant wind direction and by the role of nutcracker (Nucifraga caryocatactes) regarding the seed dispersal of Pinus cembra (Mattes 1982, 1988; Holtmeier 1993, 2000).

The use of a plant-sociological approach on primary succession patterns of glacier forelands will not be in all cases successful, this due to heterogeneous environmental conditions and due to repeated local disturbances (floods, rockfalls, avalanches), which hinder a continuously progress until full development of plant communities. Therefore, mostly permanently stable plant communities, such as Epilobietum fleischeri, will in most cases not develop to the subalpine climax stage of Larici-Pinetum cembrae. Locally defined plant communities or 'types' seem to be better suited for describing the complex spatio-temporal vegetation patterns on the foreland of the Morteratsch glacier.

Raffl et al. (2006) showed in their study on the Rotmoosferner (Ötztal, Austria) the influence of different environmental conditions on primary plant succession. They postulate two different successional pathways depending on a multitude of factors (e.g. sunny vs. shaded side). Furthermore, Erschbamer et al. (2001) and Marcante et al. (2009) stressed the high degree of heterogeneity regarding the establishment of seedlings, depending on seed rain, variability of soil seed bank, germination, mortality rates of the remaining seedlings and other factors.

Patterned structures may be associated with abrupt thresholds that either enhance or stop/hinder soil formation and vegetation development. This might be due to several causes such as microclimatic conditions, micro-relief, deposition of physically inhomogeneous parent material (sites with a more fine-grained deposit close to rock debris), disturbance and probably also to brief periglacial processes (cf. Haughland, 2004). 
Although the small-scale soil and the vegetation patterns in the pro-glacial area are very patchy and hetereogeneous, the statistical and geographical comparison of the soil and vegetation maps revealed several significant trends and interrelationships among soil development, vegetation cover and composition and time since deglaciation. This is a valuable basis for further modelling of vegetation and soils development. Grain size of the substrate, water supply, microclimate and the time since glacier retreat seem to be the main drivers of plant successions on the young, pro-glacial areas.

\section{Acknowledgements}

We are very grateful to the following persons: Dr. Andreas Rigling and Christian Ginzler (both WSL, Birmensdorf) for their support collecting vegetation data and for establishing the $40 \mathrm{~m}$-grid within the pro-glacial area of Morteratsch; Petra Kauer-Ott and Martin Steinmann for preparing some figures and tables.

\section{References}

Anderson, S.P., Drever, J.I., Frost, C.D., Holden, P., 2000. Chemical weathering in the foreland of a retreating glacier. Geochimica et Cosmochimica Acta 64, 1173-1189.

Arn, K., 2002. Geochemical weathering in the sub- and proglacial zone of two glaciated crystalline catchments in the Swiss Alps (Oberaar- and Rhoneglacier). Ph.D. Thesis, University of Neuchâtel, Neuchâtel.

Bäumler, E. 1988. Untersuchungen zur Besiedlungsdynamik und Populationsbiologie einiger Pionierpflanzen im Morteratschgletschervorfeld. Doctoral Thesis, University of Basel.

Beeler, F. 1977. GemorpholoArcGISche Untersuchungen am Spät- und Postglazial im Schweizerischen Nationalpark und im Berninapassgebiet (Südrätische Alpen). Erg. wiss. Unters. Schweiz. Nationalpark 15 (77),131-276. 
Bianchi, R. 2005. Klimaxnähe der ältesten Sukzessionsstadien auf dem Vorfeld des Morteratschgletschers. Unpublished diploma thesis Umweltwissenschaften ETH Zürich, 115 pp.

Bleuler, M. 1986. Jahrringanalysen von Lärchen in Gletschervorfeldern. Diplomarbeit Geographisches Institut Universität Zürich.

Böhmer, H.-J. 1999. Vegetationsdynamik im Hochgebirge unter dem Einfluss natürlicher Störungen. Diplomarbeit, Berlin.

Braun-Blanquet, J. 1948. Übersicht der Pflanzengesellschaften Rätiens. Vegetatio 1 (1) - 2(4-5), 1124.

Braun-Blanquet, J. 1973. Ein Schmuck der Alpengewässer, die Weidenröschen-Gesellschaft (Epilobion fleischeri). Acta Botanica Academiae Scientiarum Hungaricae 19, 47-53.

Brunner, J., Jäggli, F., Nievergelt, J., and Peyer, K. 1997. Kartieren und Beurteilen von Landwirtschaftsböden. Schriftenreihe der FAL (Eidgenössische Forschungsanstalt für Agrarökologie und Landbau) 24, Zürich-Reckenholz.

Büchi, H. 1987. Geologie und Petrographie der Bernina IX. Das Gebiet zwischen Pontresina und dem Morteratschgletscher. Diplomarbeit Universität Zürich, 153 pp.

Büchi, H. 1994. Der variskische Magmatismus in der östlichen Bernina (Graubünden, Schweiz). Schweiz. Mineral. Petrogr. Mitt. 74, 359-371.

Bugmann, H. 2005. Modeling future vegetation cover, forest dynamics and fire occurrence in mountain regions. In: Lee, C., Schaaf, T. (eds.), Global Change Research in Mountain Biosphere Reserves 2nd and 3rd Thematic Workshops, UNESCO Press, Paris, pp 64-79.

Burga, C.A. 1987. Gletscher- und Vegetationsgeschichte der Südrätischen Alpen seit der Späteiszeit (Puschlav, Livigno, Bormiese). Denkschr. Schweiz. Naturf. Ges. 101. Birkhäuser, Basel, 164 pp. Burga, C.A., Perret, R. 1998. Vegetation und Klima der Schweiz seit dem jüngeren Eiszeitalter. Ott, Thun, $832 \mathrm{pp}$.

Burga, C.A. 1999a. Vegetation development on the glacier foreland Morteratsch (Switzerland). Applied Vegetation Science 2, 17-24. 
Burga, C.A. 1999b. Vegetationsdynamik in Gletschervorfeldern der Schweizer Zentralalpen am Beispiel von Morteratsch (Pontresina, Graubünden, Schweiz). Ber. d. Reinh.-Tüxen-Ges. 11, 267277.

Burrows, C.J. 1990. Processes of vegetation change. Unwin Hyman, London, 551 pp.

Caccianiga, C., Andreis, C., Cerabolini, B. 2001. Vegetation and environmental factors during primary succession on glacier forelands: some outlines from the Italien Alps. Plant Biosystems, 135, 3, 295310.

Coaz, J. 1887. Erste Ansiedlung phanerogamer Pflanzen auf von Gletschern verlassenem Boden. Mitt. Naturforsch. Ges. Bern, 1143-68, 3-12.

Conen, F., Yakutin, M.V., Zumbrunn, T., Leifeld, J. 2007. Organic carbon and microbial biomass in two soil development chronosequences following glacial retreat. European Journal of Soil Science, 58, 758-762.

Cooper, W.S. 1923. The recent ecological history of Glacier Bay, Alaska. Ecology 23, 93-128, 223246.

Delarze, R., Gonseth, Y. 2008. Lebensräume der Schweiz. hep verlag ag, Bern.

Egli, M., Fitze, P., Mirabella, A. 2001. Weathering and evolution of soils formed on granitic, glacial deposits: results from chronosequences of Swiss alpine environments. Catena, 45, 19-47.

Egli, M. 2002. Organische Substanz, Mineralien und Verwitterungsraten in alpinen Böden als Funktion der Zeit. BGS Bulletin, 25, 55-60.

Egli, M., Mirabella, A., Fitze, P. 2003. Formation rates of smectites derived from two Holocene chronosequences in the Swiss Alps. Geoderma, 117, 81-98.

Egli, M. Wernli, M., Kneisel, C., Haeberli, W. 2006. Melting Glaciers and Soil Development in the Proglacial Area Morteratsch (Swiss Alps): I. Soil Type Chronosequence. Arctic, Antarctic, and Alpine Research, 38, 4, 499-509.

Egli, M., Merkli, C., Sartori, G., Mirabella, A., Plötze, M. 2008. Weathering, mineralogical evolution and soil organic matter along a Holocene soil toposequence on carbonate-rich materials. Geomorphology, 97, 675-696. 
Egli, M., Kneisel, C. unpubl. Soil map of the pro-glacial area Morteratsch.

Elsener, S. 2006. Besiedlungsdynamik von Arve (Pinus cembra L.) und Lärche (Larix decidua Mill.) im Vorfeld des Morteratschgletschers. Unpublished diploma thesis Geographisches Institut der Universität Zürich, $121 \mathrm{pp}$.

Erschbamer, B. 1997. Climate warming and plant growth on glacial retreats. Actes du deuxième Colloque Ecologie et Biogéographie Alpines Botanique et Zoologie - Suppl. Rev. Valdôtaine d'Histoire Naturelle, 51, 219-224.

Erschbamer, B., Kneringer, E., Niederfriniger Schlag, R. 2001. Seed rain, soil seed bank, seedling recruitment, and survival of seedlings on a glacier foreland in the Central Alps. Flora, 196, 304-312.

Erschbamer, B. 2007. Winners and Losers of Climate Change in a Central Alpine Glacier Foreland. Arctic, Antarctic and Alpine Research, 39,2, 237-244.

FAO 1998. World Reference Base for Soil Resources (WRB). World Soil Resources Reports 84, Rome.

FAO - UNESCO 1990. Soil Map of the World - Revised Legend. Rome, Italy.

Fischer, M. 1999. Waldgrenzökoton und Wiederbewaldungsdynamik im Gebiet des Morteratschgletschers. Unpublished diploma thesis Geographisches Institut der Universität Zürich, $149 \mathrm{pp}$.

Fitze, P.F. 1982. Zur Relativdatierung von Moränen aus der Sicht der Bodenentwicklung in den kristallinen Zentralalpen, Catena, 9, 265 - 306.

Fossati, A. 1980. Keimverhalten und frühe Entwicklungsphasen einiger Alpenpflanzen. Veröff. Geobot. Inst. ETH Stiftung Rübel, Zürich 73.

Frahm, J.-P., Frey, W. 1983. Moosflora. Ulmer, Stuttgart.

Friedel, H. 1938. Die Pflanzenbesiedlung im Vorfeld des Hintereisferners. Z. Gletscherkd. Glazialgeol. $26,215-239$

Friedel, H. 1956. Die alpine Vegetation des obersten Mölltales (Hohe Tauern). Erläuterung zur Vegetationskarte der Umgebung der Pasterze. Wiss. Alpenvereinshefte 16. Innsbruck. 
Furrer, G. 1991. 25000 Jahre Gletschergeschichte. Neujahrsblatt Naturf. Ges. in Zürich, Orell Füssli, Zürich, 193 pp.

Gafner, R., Hess, T. 1994. Vegetationsdynamik am Sesvennagletscher. Diplomarbeit Geographisches Institut der Universität Zürich.

Gamper, B., Suter, J. 1982. Gletscher-, Vegetations- und Klimageschichte im Oberengadin. In: Maisch, M., Suter, J. (eds.) Exkursionsführer Teil A: Ostschweiz. Physische Geographie 6, 14-17. Gerber, B. 1995. Das Projekt "IGLES". Inventar der Gletschervorfelder und alpinen Schwemmebenen als Ergänzung des Bundesinventars der Auengebiete von nationaler Bedeutung. Regio Basiliensis, Basler Zeitschrift für Geographie 36 (2): Geomorphologie für die Praxis - Geomorphologie in der Praxis. Schweiz. Geom. Gesellschaft, 174. Jahresversammlung der SANW 1994, 201-208.

Gletscherberichte (1881-2008) "Die Gletscher der Schweizer Alpen", Jahrbücher der Expertenkommission für Kryosphärenmessnetze der Akademie der Naturwissenschaften Schweiz (SCNAT) herausgegegeben seit 1964 durch die Versuchsanstalt für Wasserbau, Hydrologie und Glaziologie (VAW) der ETH Zürich. No. 1-124, (http://glaziology.ethz.ch/swiss-glaciers/).

Greig-Smith, P. 1983. Quantitative plant ecology. Blackwell scientific publications, Oxford, 359 pp. Haeberli, W., Keller, F., Krüsi, B., Egli, M., Rothenbühler, C., Meilwes, J., Gruber, S. (eds.) 2007. Raum-zeitliche Informationen über schnelle Klimaänderungen in hochalpinen Umweltsystemen als strategisches Werkzeug für Analyse, Kommunikation, partizipative Planung und Management im Tourismusgebiet Oberengadin. Schlussbericht des Teilprojektes GISALP NFP48 (Nationales Forschungsprogramm "Landschaften und Lebensräume der Alpen”). vdf Hochschulverlag AG an der ETH-Z, Zürich, 213 pp.

Hangartner, S. 2005. Möglichkeiten zur dynamischen 3D-Visualisierung von simulierten Pflanzensukzessionen am Beispiel des Gletschervorfeldes Morteratsch. Diplomarbeit Geographisches Institut der Universität Zürich.

Haugland, J. E. 2004: Formation of patterned ground and fine-scale soil development within two late Holocene glacial chronosequences: Jotunheimen, Norway. Geomorphology, 61, 287 - 301. 
Heitz, A.K., Punchakunnel, P., Zoller, H. 1982. Vegetations-, Klima- und Gletschergeschichte des Oberengadins. Physische Geographie 1, 157-170.

Herzog, T. 1912. Die Moosformationen. In: Rübel, E., Pflanzengeographische Monographie des Berninagebietes. Bot. Jahrb. 47, pp. 235-250.

Hitz, C., 2002. Inventur und Dynamik der organischen Substanz in Böden der alpinen Stufe. Schriftenreihe Physische Geographie, 42, Universität Zürich.

Holtmeier, F. K. 1993. Der Einfluss der Generativen und vegetativen Verjüngung auf das Verbreitungsmuster der Bäume und die ökoloArcGISche Dynamik im Waldgrenzbereich.

Beobachtungen und Untersuchungen in Hochgebirgen Nordamerikas und den Alpen. Bensheim, Geoökodynamik, XIV, 153-182.

Holtmeier, F. K. 2000. Die Höhengrenze der Gebirgswälder. Institut für Landschaftsökologie Westfälische Wilhelms-Universität, Münster, 337pp.

Holzhauser, H., Zumbühl, H. 1996. To the history of the Lower Grindelwald Glacier during the last 2800 years - palaeosols, fossil wood and historical pictorial records - new results. Z. Geomorph. N.F. Suppl. 104, 95-127.

Hosein, R, Arn, K., Steinmann, P., Adatte, T., Föllmi, K.B., 2004. Carbonate and silicate weathering in two presently glaciated, crystalline catchments in the Swiss Alps. Geochimica et Cosmochimica Acta 68, 1021-1033.

Jenny, H. 1980. The soil resource. Origin and Behavior. Ecological Studies 37, Springer-Verlag, New York.

Jochimsen, M. 1963. Vegetationsentwicklung im hochalpinen Neuland. Beobachtungen an

Dauerflächen im Gletschervorfeld 1958-1962. Ber. Naturwiss. Med. Ver. Innsbruck 53,109-123. Jones, G.A., Henry, G.H.R. 2003. Primary plant succession on recently deglaciated terrain in the Canadian High Arctic. Journal of Biogeography, 30, 277-296. Jones, C.C., Moral, R. 2005. Patterns of primary succession on the foreland of Coleman Glacier, Washington, USA. Plant Ecology 180, 105-116 doi: 110.1007/s11258-11005-12843-11251. 
Kinzl, H. 1932. Die grössten nacheiszeitlichen Gletschervorstösse in den Schweizer Alpen und in der Mt. Blanc-Gruppe. Z.Gletscherkd. Glazialgeol. 20, 269-397.

Kleiber, H. 1974. Pollenanalytische Untersuchungen zum Eisrückzug und zur Vegetationsgeschichte im Oberengadin. Bot. Jahrb. Syst. 94, 1-53.

Kratochwil, A., Schwabe, A. 1994. Coincidences between different landscape ecological zones and growth forms of Cembran pine (Pinus cembra L.) in subalpine habitats of the Central Alps. Landscape Ecology 9,3, 175-190.

Krüsi, B., Burga, C., Elsener, S., Rigling, A., Bianchi, R., Ebert, M., Paul, F., Ziefle, M. Vegetation. In: Haeberli, W., Keller, F., Krüsi, B., Egli, M., Rothenbühler, C., Meilwes, J., Gruber, S. (eds.) 2007. Raum-zeitliche Informationen über schnelle Klimaänderungen in hochalpinen Umweltsystemen als strategisches Werkzeug für Analyse, Kommunikation, partizipative Planung und Management im Tourismusgebiet Oberengadin. Schlussbericht des Teilprojektes GISALP NFP48 (Nationales Forschungsprogramm "Landschaften und Lebensräume der Alpen"), vdf Hochschulverlag AG an der ETH-Z, Zürich, pp 69-88.

Lauber, K., Wagner, G. 2007. Flora Helvetica. $4^{\text {th }}$ ed. Haupt, Bern, Stuttgart, Wien.

Lichter, J., 1998. Rates of weathering and chemical depletion in soils across a chronosequence of Lake Michigan sand dunes. Geoderma, 85: 255-282.

Lüdi, W. 1921. Die Pflanzengesellschaften des Lauterbrunnentales und ihre Sukzession. Beitr. Geobot. Landesaufn. Schweiz 9, 364 pp.

Lüdi, W. 1934. Beitrag zur Kenntnis der Beziehungen zwischen Vegetation und Boden im östlichen Aarmassiv. Ber. Geobot. Forsch. Inst. Rübel Zürich 1933, 41-54.

Lüdi, W. 1945. Besiedlung und Vegetationsentwicklung auf den jungen Seitenmoränen des Grossen Aletschgletschers mit einem Vergleich der Besiedlung im Vorfeld des Rhonegletschers und des Oberen Grindelwaldgletschers. Ber. Geobot. Forsch. Inst. Rübel Zürich 1944, 35-112.

Lüdi, W. 1950. Die Pflanzenwelt des Aletschwald-Reservats bei Brig. Bull. Murithienne 67, 123-178. Lüdi, W. 1955. Die Vegetationsentwicklung seit dem Rückzug der Gletscher in den mittleren Alpen und ihrem nördlichen Vorland. Ber. Geobot. Forsch. Inst. Rübel Zürich 1954, 36-68. 
Lüdi, W. 1958. Beobachtungen über die Besiedlung von Gletschervorfeldern in den Schweizeralpen. Flora 146, 386-407.

Maisch, M. 1992. Die Gletscher Graubündens. Rekonstruktion und Auswertung der Gletscher und deren Veränderungen seit dem Hochstand von 1850 im Gebiet der östlichen Schweizer Alpen (Bündnerland und angrenzende Regionen). Teil A: Grundlangen-Analysen-Ergebnisse. Teil B: Verzeichnisse-Datenkataloge-Gletscherkarten. Phys. Geographie 33. Geographisches Institut der Universität Zürich.

Maisch, M., Suter, J. (Eds.) 1982. Exkursionsführer Teil A: Ostschweiz. Physische Geographie 6, 71 pp.

Maisch, M., Burga, C.A., Fitze, P. 1993. Lebendiges Gletschervorfeld. Führer und Begleitbuch zum Gletscherlehrpfad Morteratsch. Engadin-Press, Samedan, 138 pp.

Maisch, M. 1999. The signal of climate change in the Swiss Alps: Glacier retreat since the end of the Little Ice Age and future perspectives. Comune di Sondrio - Assessorato della Cultura: 11. Sondrio Festival 1997. Mostra Internazionale dei Documentari siu Parchi - Convegno Ghiacciai e aree protette: Conoscenza, Conservazione, Valorizzazione.

Marcante, S., Schwienbacher, E., Erschbamer, B. 2009. Genesis of a soil seed bank on a primary succession in the Central Alps (Ötztal, Austria). Flora, article in press.

Mattes, H. 1982. Die Lebensgemeinschaft von Tannenhäher und Arve. Berichte 241, Eidg. Anst. forstl. Versuchswesen, Birmensdorf, $74 \mathrm{pp}$.

Mattes, H. 1988. Untersuchungen zur Ökologie und Biogeographie der Vogelgemeinschaften des Lärchen - Arvenwaldes im Engadin. Münstersche Geographische Arbeiten 30, Schöningh Paderborn, $138 \mathrm{pp}$.

Matthews, J.A. 1992. The ecology of recently-deglaciated terrain. Cambridge University Press, Cambridge, 386 pp.

Matthews, J.A., Whittaker, R.J., 1987. Vegetation succession on the Storbreen glacier foreland, Jotunheimen, Norway: A review. Arctic and Alpine Research 19, 385-395. 
Münch, A. 2001. Vegetationsdynamik im Morteratschgletschervorfeld am Beispiel von Sträuchern und späten Pionierpflanzen. Diplomarbeit, Universität Würzburg

Oechslin, M. 1935. Beitrag zur Kenntnis der pflanzlichen Besiedlung der durch Gletscher freigegebenen Grundmoränenböden. Ber. Naturforsch. Ges. Uri 4, 27-48.

Patzelt, G. 1973. Die neuzeitlichen Gletscherschwankungen in der Venedigergruppe, Zeitschrift für Gletscherkunde und Glazialgeologie, IX, 5-57.

Patzelt, G. 1985. The period of glacier advances in the Alps, 1965 to 1980. Z.Gletscherkd. Glazialgeol. 21, 403-407.

Pauli, H., Gottfried, M., Reiter, K., Klettner, C., Grabherr, G. 2006. Signals of range expansions and contractions of vascular plants in the high Alps: observations (1994-2004) at the GLORIA master site Schrankogel, Tyrol, Austria. Global Change Biology, 12, 1-10.

Punchakunnel, P. 1983. Pollenanalytische Untersuchungen zum Eisrückzug und zur Vegetationsgeschichte im Oberengadin II (Lej Marsch, Mauntschas, Stazerwald). Dissertation Botanisches Institut Universität Basel, 105 pp.

Raffl, C., Mallaun, M., Mayer, R., Erschbamer, B. 2006. Vegetation Successsion Pattern and Diversity Changes in a Glacier Valley, Central Alps, Austria. Arctic, Antarctic and Alpine Research, 38, 3, 421-428.

Rageth, R. 1984. Intrusiva und Extrusiva der Bernina-Decke zwischen Morteratsch und Berninapass (Graubünden). Schweiz. Mineral. Petrogr. Mitt. 64, 83-109.

Rehberger, S. 2002. Vegetationsdynamik auf Moränendauerflächen des Grossen Aletschgletschers im Wallis. Geographica Helvetica, 57 (3), 184-193.

Richard, J.-L. 1973. Dynamique de la végétation au bord du Grand Glacier d'Aletsch (Alpes suisses). Ber. Schweiz. Bot. Ges. 83, 159-174.

Richard, J.-L. 1987. Dynamique de la végétation sur les marges glaciaires récentes de la reserve d'Aletsch (Alpes valaisannes, Suisse). 15 ans d'observations dans les placettes-témoins (19711986). Bot. Helv. 97, 265-275. 
Richter, M. 1994. Die Pflanzensukzession im Vorfeld des Tschierva-Gletschers/ Oberengadin. Geoökodynamik 15, 55-88.

Röthlisberger, F. 1986. 10’000 Jahre Gletschergeschichte der Erde. Sauerländer, Aarau, 416 pp.

Rübel, E. 1912. Pflanzengeographische Monographie des Berninagebietes. Bot. Jahrb. 47, 615 pp.

Runge, F. 1994. Die Pflanzengesellschaften Mitteleuropas. Aschendorff, Münster, 312 pp.

Schubiger, C. 1988. Die Vegetation des Rhonegletschervorfeldes, ihre Sukzession und naturräumliche Gliederung. Beitr. Geobot. Landesaufn. Schweiz 64. Krypto, Teufen.

Schwarz, R. 2001. Vegetationsdynamik im Morteratschgletschervorfeld am Beispiel von Sträuchern und späten Pionierpflanzen. Diplomarbeit, Universität Würzburg.

Spillmann, P. 1993. Die Geologie des penninisch-ostalpinen Grenzbereichs im südlichen Berninagebirge. Dissertation ETH No.10'175, Zürich.

Staub, R. 1946. GeoloArcGISche Karte der Bernina-Gruppe und ihrer Umgebung im Oberengadin, Bergell, Val Malenco, Puschlav und Livigno. 1:50'000. GeoloArcGISche Spezialkarte 118, Schweizerische GeoloArcGISche Kommission, Basel.

Stöcklin, J., Favre, P. 1994. Effects of plant size and morphological constraints on variation in reproductive components in two related species of Epilobium. Journal of Ecology 82, 735-746.

Stöcklin, J., Bäumler, E. 1996. Seed rain, seedling establishment and clonal growth strategies on a glacier foreland. Journal of Vegetation Science 7, 45-56.

Stuart, C.F., Walker, L.R., Fastie, C.L., Sharman, L.C. 1994. Mechanisms of primary succession following deglaciation at Glacier Bay, Alaska. Ecological Monographs, 64, 2, 149-175.

Treter, U., Ramsbeck-Ullmann, M., Böhmer, H. J., Bösche, H. 2002. Vegetationsdynamik im Vorfeld des Lys-Gletschers (Valle di Gressoney/ Region Aosta/ Italien) seit 1821. Erdkunde, 56, 253-267.

Urbanska, K.M., Schütz, M. 1986. Reproduction by seed in alpine plantes and revegetation research above timberline. Bot. Helv. 96,1, 43-60.

Vittoz, P., Bodin, J., Ungricht, S., Burga C.A., Walther, G.-R. 2007. One century of vegetation change on the Isla Persa, a nunatak in the Bernina massif in the Swiss Alps. Accepted by Journal of Vegetation Science. 
von Klebelsberg, R. 1913. Das Vordringen der Hochgebirgsvegetation in den Tiroler Alpen. Österr. Bot. Z. $63,177-186,241-254$.

Walther, G.-R., Beißner, S., Burga, C.A. 2005. Trends in the upward shift of alpine plants. Journal of Vegetation Science, 16, 541-548.

Wellstein, C., Uehlinger, U., Zah, R. 2003. Terrestrial floodplain vegetation. In: Ward, J.V., Uehlinger, U. (eds.) Ecology of a Glacial Floodplain, 109-121. Kluwer Academic Publishers, Dordrecht.

Wernli, M. 2005. Klimabedingte Veränderungen von Böden: Analyse im Gletschervorfeld mittels bodenkundlicher Methoden und GIS. Diplomarbeit Geographisches Institut Universität Zürich, 98 pp.

Wirth, V. 1995. Flechtenflora. Ulmer, Stuttgart.

Ziefle, M. 2006. Gletscherschwund und Vegetationsdynamik in Morteratsch (Pontresina, Schweiz). Unpublished diploma thesis Geographisches Institut der Universität Zürich, 95 pp.

Zoller, H., Athanasiadis, N., Heitz-Weniger, A. 1998. Late-glacial and Holocene vegetation and climate change at the Palü glacier, Bernina Pass, Grisons Canton, Switzerland. Veget Hist Archaeobot 7 , 241-249.

Zumbühl, H., Holzhauser, H. 1988. Alpengletscher in der Kleinen Eiszeit. Die Alpen 64 (3). Sonderheft zum 125jährigen Jubiläum des Schweizer Alpen-Club.

\section{Captions to figures and tables}

\section{Figures}

Fig. 1: Investigation area and vegetation map of the glacier foreland Morteratsch $(1900-2100 \mathrm{~m}$ a.s.I). The lines mark the approximate position of the end of the glacier between 1857 and 1997 (after Burga, 1999b). Note the special edition of the Swiss stamp 2009 dedicated to the Morteratsch glacier. Source: @Die Post. 
Fig. 2: Investigation area of the glacier foreland Morteratsch with more accurate former positions of the glacier for the time span 1940-2000 and with the established grid with a mesh width of 40 m (bright dots).

Fig. 3: Generalised chronosequence of pioneer plants 1857-1990 (vascular plants and lichens, after Burga, 1999a,b)

Fig. 4: Generalised chronosequence of subalpine forest and dwarf shrub heath species 1857-1990 (after Burga, 1999a,b)

Fig. 5: Comparison between the spatial distribution of soil types and vegetation units.

Fig. 6 a, b: Temporal evolution of a) the soil skeleton content (material with a diameter $>2 \mathrm{~mm}$; referred to a standardised soil depth of $15 \mathrm{~cm})$ and b) abundance of soil organic matter $\left(\mathrm{kg} / \mathrm{m}^{2} \mathrm{C}\right)$ in the pro-glacial area

Fig. 7: Temporal development of the relative proportion of the most important vegetation types (see also Fig. 1) of the vegetation-covered area of the glacier foreland Morteratsch as a function of time (data from figs. 2 and 5)

Fig. 8: Primary plant successions of the glacier foreland Morteratsch: model based on different starting points of different potential primary successions and grain size classes (non-linear micro-site primary succession model) 
Tables

Tab. 1: Ecological properties of pioneer plants occurring in the glacier foreland Morteratsch

Tab. 2: Selected chemical and physical properties of 11 typical soil profiles in the pro-glacial area

Tab. 3: Soil moisture of four monitored sites (two different soil types) in the pro-glacial area

Tab. 4: Comparison of vegetation with soil data of the glacier foreland Morteratsch

Tab. 5: Absolute and relative distribution of vegetation units within the pro-glacial area with respect to the soil types

Tab. 6: Relative distribution of the vegetation types in respect to the grain sizes (soil) 


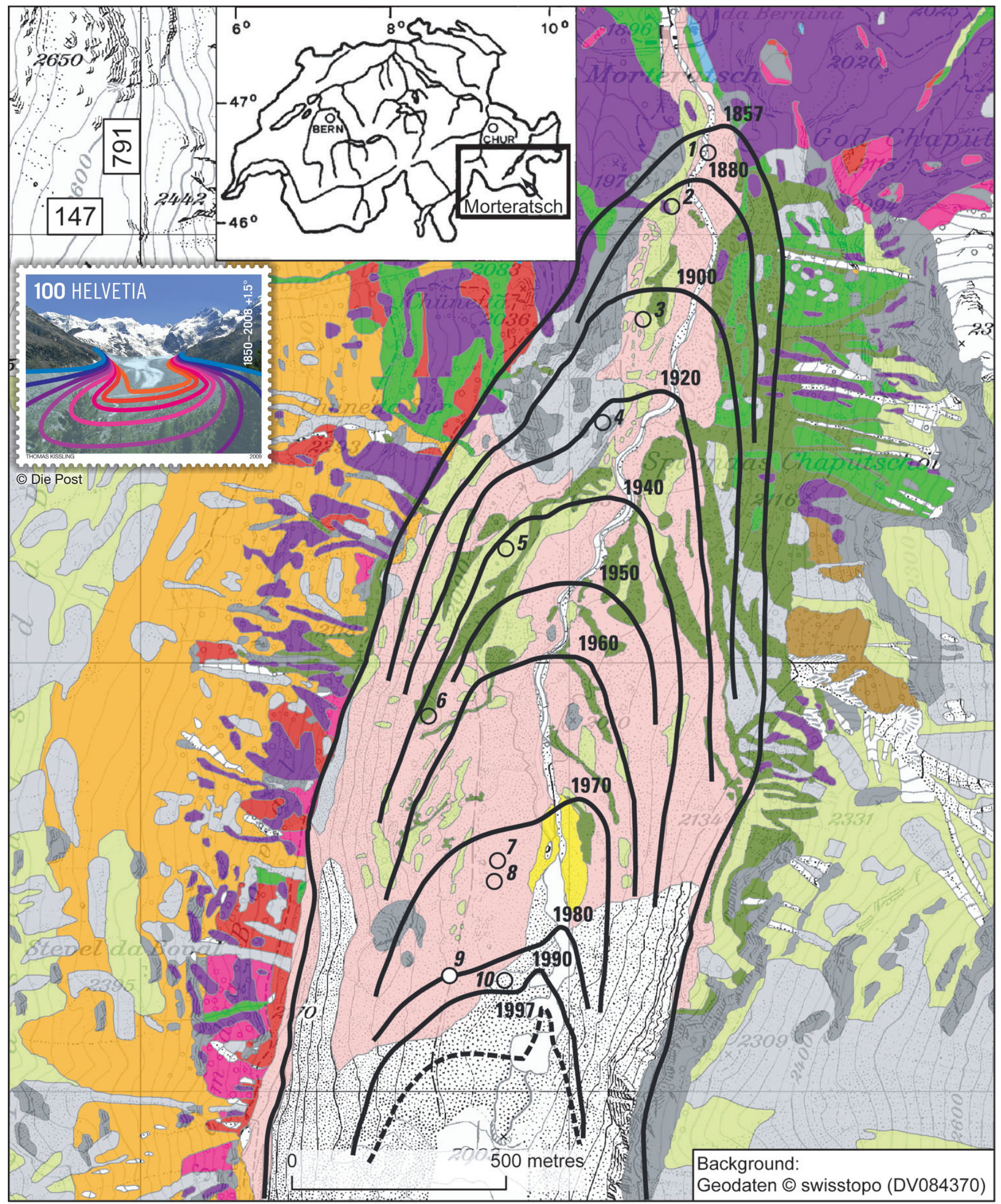
Larch-Swiss stone pine forest (Larici-Pinetum cembrae),
partially Swiss stone pine forest

Open larch-Swiss stone pine forest

Dwarf shrub heath (Rhododendro-Vaccinietum Empetro-Vaccinietum, Junipero-Arctostaphyletum)

Mosaic structure of dwarf shrub heath with Juniperus communis ssp. nana and Nardus stricta grass heath

Green alder scrub (single stands of shrubs and Alnetum viridis)

European dwarf-pine scrub

Grass heath on moister soils (Dystric Cambisols, grass species e.g. Festuca violacea, Calamagrostis villosa, Phleum rhaeticum Poa alpina)

Pioneer grass communities. Outside of the pro-glacial area grass heath (Geo montani-Nardetum and Poion alpinae, above approx. $2400 \mathrm{~m}$ Caricetum curvulae)
Epilobietum fleischeri with single willow shrubs (on older sites with alpenrose)

Oxyrietum digynae with Myricaria germanica, Saxifraga aizoides, Linaria alpina and moss cushions (Rhacomitrium spec., Pohlia spec.)

Boulder plant communities, partially Epilobietum fleischeri, Adenostyles leucophylla and several fern species

Rock vegetation (e.g. Agrostis rupestris, Silene rupestris, Sempervivum arachnoideum)

Peat bog, ancient lake mire

$\square$ No vegetation, bedrock, rock debris, glacier ice, brooks

Glacier stages 1857 - 1997 Number $1-10$ permanent vegetation
monitoring plots $\left(16 \mathrm{~m}^{2}-400 \mathrm{~m}^{2}\right)$ 


\section{Glacier foreland Morteratsch}

Glacier stages 1857 - 2004

Grid of investigated area (bright dots) $40 \mathrm{~m}$

Floods of 1955 and 1987

$0.125 \quad 250 \quad 500$

Metres

Flood 1955
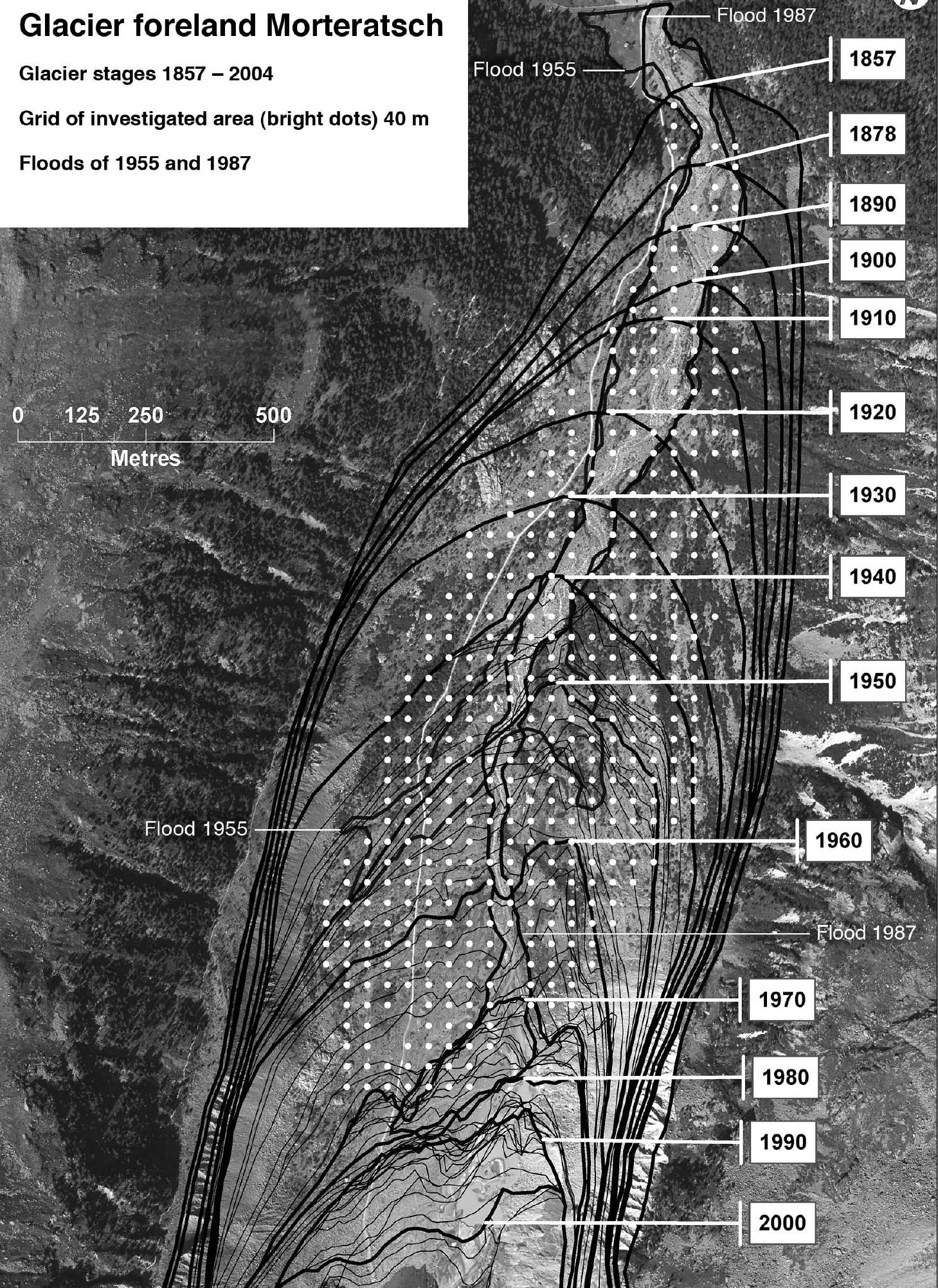


\begin{tabular}{|c|c|c|c|c|c|c|c|c|c|c|c|}
\hline Glacier stage (years A.D.) & $\sim 1990$ & 1985 & 1980 & 1970 & 1960 & 1950 & 1940 & 1920 & 1900 & 1878 & 1857 \\
\hline Age of icefree areas $1857-1997$ (years) & $\sim 7$ & 12 & 17 & 27 & 37 & 47 & 57 & 77 & 97 & 119 & 140 \\
\hline $\begin{array}{l}\text { Approx. distance (metres) from the present } \\
\text { (1997) end of glacier (axis of the valley) }\end{array}$ & 100 & 150 & 200 & 500 & 800 & 970 & 1170 & 1440 & 1660 & 1920 & 2050 \\
\hline \multicolumn{12}{|l|}{$\begin{array}{l}\text { Pioneer plants and lichens } \\
\text { (dominant species) }\end{array}$} \\
\hline \multicolumn{12}{|l|}{ Epilobium fleischeri } \\
\hline Linaria alpina & ........... & .......... & & & & & & & & & \\
\hline \multicolumn{12}{|c|}{ Saxifraga aizoides } \\
\hline \multicolumn{12}{|l|}{ Rumex scutatus } \\
\hline \multicolumn{12}{|l|}{ Oxyria digyna } \\
\hline \multirow{2}{*}{\multicolumn{12}{|c|}{$\begin{array}{l}\text { Saxifraga bryoides } \\
\text { Adenostyles leucophylla }\end{array}$}} \\
\hline & & ....... & & & --- & ---- & & & & & \\
\hline \multicolumn{12}{|l|}{ Poa nemoralis } \\
\hline \multicolumn{12}{|l|}{ Achillea moschata } \\
\hline \multicolumn{12}{|l|}{ Trifolium pallescens } \\
\hline \multicolumn{12}{|l|}{ Cerastium pedunculatum } \\
\hline \multicolumn{12}{|l|}{ Cardamine resedifolia } \\
\hline \multicolumn{12}{|l|}{ Cerastium uniflorum } \\
\hline \multicolumn{12}{|l|}{$\begin{array}{r}\text { Salix spp. } \\
\text { Alnus viridis }\end{array}$} \\
\hline \multicolumn{12}{|l|}{ Alnus viridis } \\
\hline \multicolumn{12}{|l|}{ Rhacomitrium canescens } \\
\hline & & ........... & 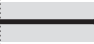 & $\circ \circ \circ \circ$ & 00000 & (........... & & & & & \\
\hline \multicolumn{12}{|c|}{ 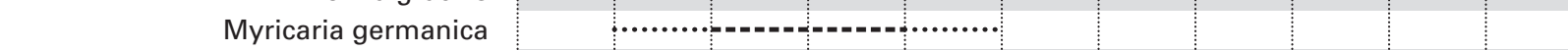 } \\
\hline \multicolumn{12}{|l|}{ Geum reptans } \\
\hline \multicolumn{12}{|l|}{ Hieracium staticifolium } \\
\hline Stereocaulon alpinum & & & $\cdots \cdots$ & & $\cdots \cdots \cdot$ & & $\cdots \cdots \cdots$ & & ........... & & \\
\hline Rhizocarpon geographicum & & & & & & & & & & & \\
\hline
\end{tabular}

Legend to the tables 1-3 (plant species occurrence along the chronosequence of the glacier forefield)

\section{Cover-abundance}

......... present rarely (Br.-BI. $>$ r and $<+$ )

-.-- present infrequently, low cover-abundance (Br. -BI. +)

- present frequently, low cover-abundance (Br.-BI. 1, $<5 \%$ )

- - - present frequently, moderate cover-abundance (Br.-BI. 2, 5-25\%)

present frequently, high cover-abundance (Br.-BI. 3-4, $>25 \%$ )

$\circ 000$ locally higher cover-abundance $(>75 \%)$ 


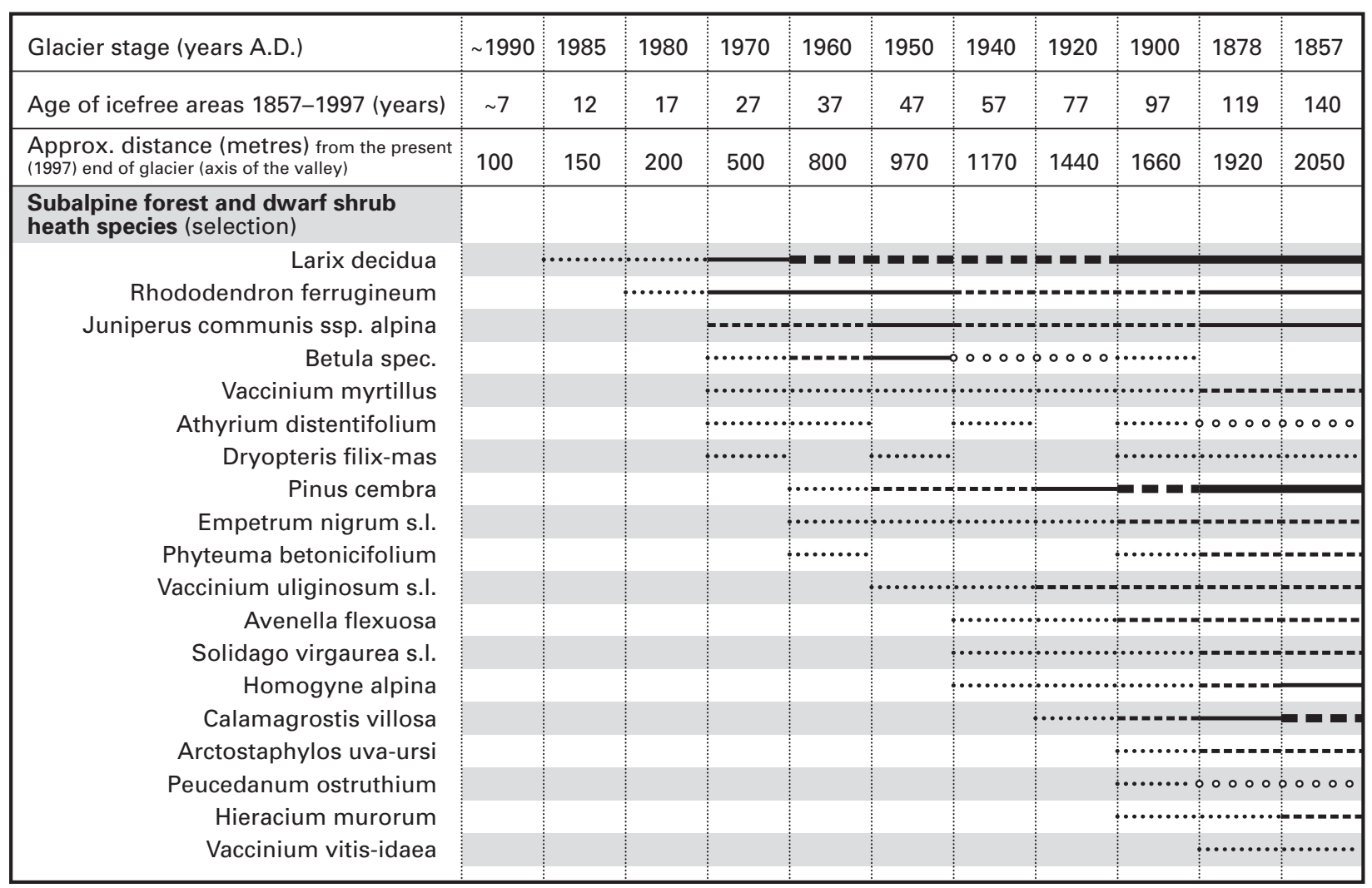




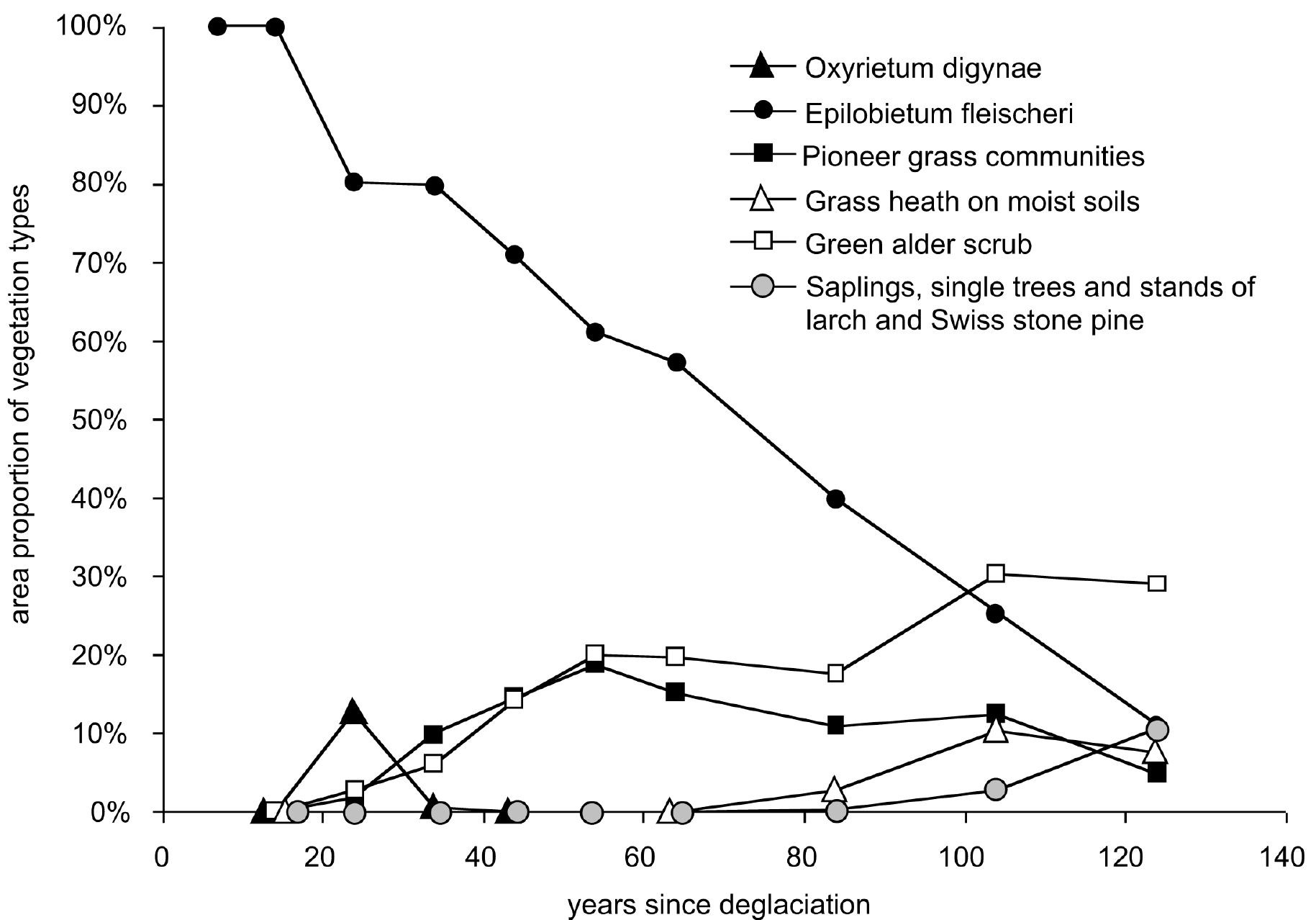


Primary plant successions of the glacier foreland Morteratsch: different starting points

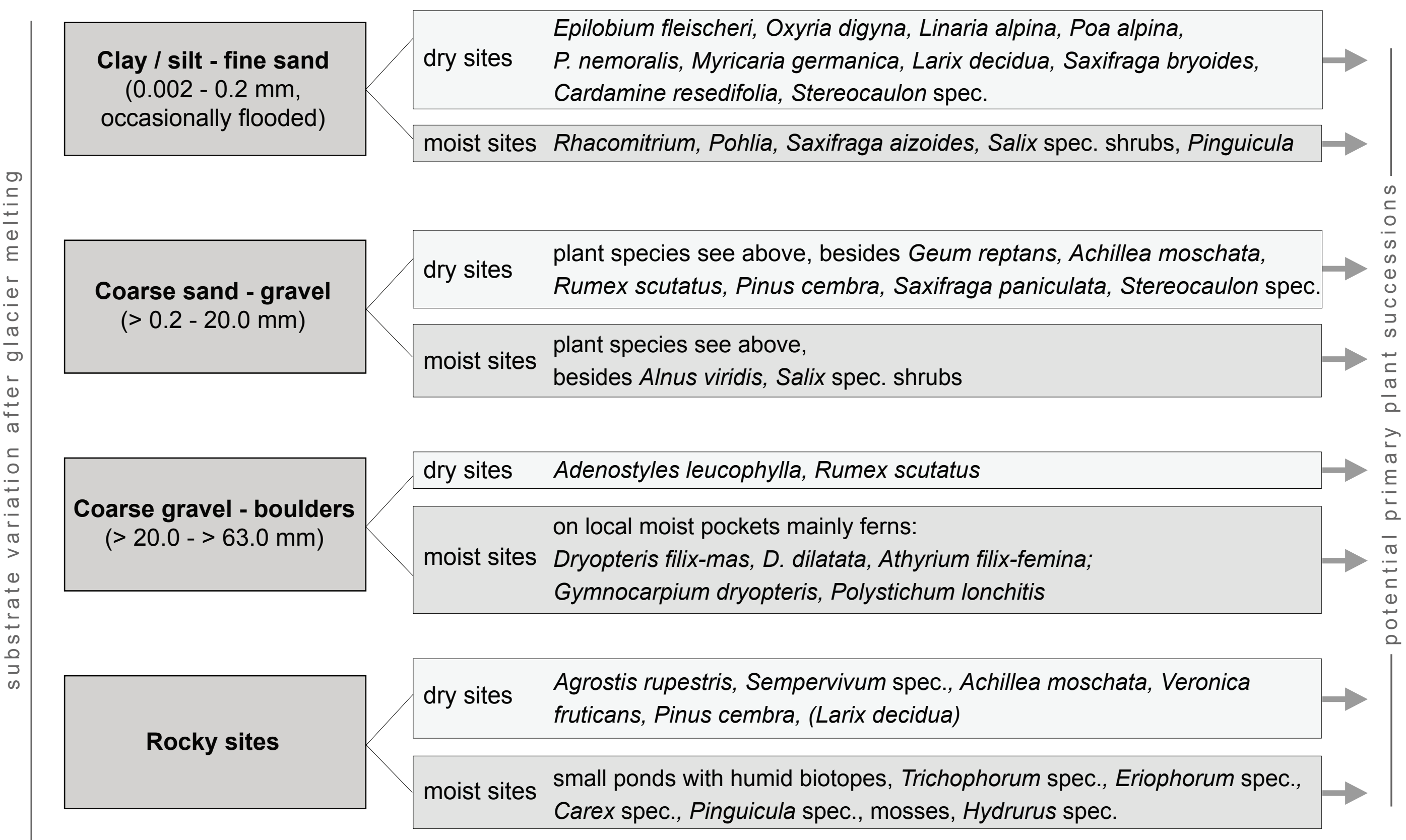




\begin{tabular}{|c|c|c|c|c|c|c|c|c|c|c|c|}
\hline \multirow[t]{2}{*}{ Plant species } & \multicolumn{5}{|c|}{$\begin{array}{l}\text { Ecological indicator values } \\
\text { (Landolt 1977) }\end{array}$} & \multirow[t]{2}{*}{$\begin{array}{l}\text { Life } \\
\text { form }\end{array}$} & \multicolumn{5}{|c|}{ preferred sites (dominant grain size of substrate) } \\
\hline & $\mathrm{F}$ & $\mathrm{R}$ & $\mathrm{N}$ & $\mathrm{L}$ & $\mathrm{D}$ & & $\begin{array}{l}1 \text { clay / silt- } \\
\text { fine sand }\end{array}$ & $\begin{array}{c}2 \text { coarse } \\
\text { sand-gravel }\end{array}$ & $\begin{array}{l}\beta \text { coarse gra } \\
\text { vel-boulders }\end{array}$ & $\begin{array}{l}\text { rock } \\
\text { sites }\end{array}$ & $\begin{array}{c}\text { small ponds/ } \\
\text { mires }\end{array}$ \\
\hline Rhacomitrium canescens & - & - & - & - & - & $\bar{c}$ & $\mathrm{x}$ & & & & \\
\hline Pohlia spec. & - & - & - & - & - & C & $x$ & & & & \\
\hline Saxifraga aizoides & $4 \mathrm{w}$ & 5 & 2 & 4 & $\mathrm{x}$ & $\mathrm{C}$ & $x$ & & & & $\mathrm{x}$ \\
\hline & & & & & & & & & & & \\
\hline Epilobium fleischeri & $3 w$ & 4 & 3 & 5 & 2 & $\mathrm{C}$ & $x$ & $x$ & & & \\
\hline Linaria alpina & 4 & 4 & 2 & 5 & 2 & $\mathrm{C}$ & $x$ & $x$ & & & \\
\hline Oxyria digyna & 3 & 3 & 2 & 5 & 2 & $\mathrm{~h}$ & $x$ & $x$ & & & \\
\hline Hieracium staticifolium & $2 \mathrm{w}$ & 3 & 2 & 4 & 2 & $\mathrm{~h}$ & $\mathrm{x}$ & $x$ & & & \\
\hline Cardamine resedifolia & 3 & 2 & 2 & 4 & 2 & $\mathrm{~h}$ & $x$ & $x$ & & & \\
\hline Saxifraga bryoides & 3 & 2 & 1 & 5 & 2 & $\bar{c}$ & $x$ & $x$ & & & \\
\hline Cerastium uniflorum & 3 & 2 & 2 & 5 & 2 & $\mathrm{C}$ & $x$ & $x$ & & & \\
\hline Cerastium pedunculatum & 3 & 2 & 2 & 5 & 2 & C & $x$ & $x$ & & & \\
\hline Leucanthemopsis alpina & 3 & 2 & 2 & 5 & 4 & $\mathrm{~h}$ & $x$ & $\mathrm{x}$ & & & \\
\hline Poa alpina & 3 & 3 & 4 & 4 & 4 & $\mathrm{~h}$ & $x$ & $x$ & & & \\
\hline Poa nemoralis & 2 & 3 & 3 & 3 & 3 & $\mathrm{~h}$ & $x$ & $x$ & & & \\
\hline Festuca rubra s.l. & 3 & 3 & 3 & 4 & 4 & $\mathrm{~h}$ & $x$ & $x$ & & & \\
\hline Phleum rhaeticum & 3 & 3 & 4 & 4 & 4 & $\mathrm{~h}$ & $\mathrm{x}$ & $\mathrm{x}$ & & & \\
\hline Avenella flexuosa & 2 & 2 & 2 & 2 & 4 & $\mathrm{~h}$ & $x$ & $x$ & & & \\
\hline Deschampsia caespitosa & $4 w$ & 3 & 4 & 3 & 5 & $\mathrm{~h}$ & $x$ & $x$ & & & \\
\hline Myricaria germanica & $3 w$ & 4 & 2 & 4 & 3 & en & $x$ & $x$ & & & \\
\hline Larix decidua & 3 & 3 & 2 & 4 & 4 & $p$ & $x$ & $x$ & & & \\
\hline Salix nigricans & $4 w$ & 3 & 3 & 4 & 4 & $p$ & $x$ & $x$ & & & \\
\hline Salix daphnoides & $4 w$ & 4 & 2 & 4 & 3 & $p$ & $x$ & $x$ & & & \\
\hline Salix appendiculata & $4 w$ & 3 & 3 & 3 & 5 & $\mathrm{p}$ & $x$ & $x$ & & & \\
\hline Salix purpurea & $3 w$ & 3 & 3 & 4 & 3 & $p$ & $x$ & $x$ & & & \\
\hline Salix hastata & 4 & 3 & 3 & 3 & 3 & $\mathrm{n}$ & $\mathrm{x}$ & $\mathrm{x}$ & & & \\
\hline & & & & & & & & & & & \\
\hline Rumex scutatus & 2 & 3 & 2 & 4 & 2 & $\mathrm{~h}$ & & $x$ & & & \\
\hline Geum reptans & 3 & 2 & 2 & 5 & 2 & $\mathrm{~h}$ & & $x$ & & & \\
\hline Achillea moschata & 3 & 2 & 2 & 5 & 2 & $\mathrm{~h}$ & & $x$ & & & \\
\hline Lotus alpinus & 3 & 3 & 3 & 5 & 3 & $\mathrm{~h}$ & & $x$ & & & \\
\hline Trifolium badium & 3 & 4 & 3 & 4 & 4 & $\mathrm{~h}$ & & $x$ & & & \\
\hline Trifolium pallescens & 3 & 2 & 2 & 4 & 2 & $\mathrm{~h}$ & & $x$ & & & \\
\hline Trifolium pratense ssp. nivale & 3 & 3 & 3 & 4 & 4 & $\mathrm{~h}$ & & $x$ & & & \\
\hline Saxifraga paniculata & 2 & 4 & 2 & 5 & 1 & $\mathrm{C}$ & & $\mathrm{x}$ & & $\mathrm{x}$ & \\
\hline Alnus viridis & $4 w$ & 2 & 4 & 4 & 5 & $n$ & & $x$ & & & \\
\hline Pinus cembra & 3 & 2 & 2 & 3 & 4 & ep & & $\mathrm{x}$ & & & \\
\hline Betula pubescens & $\mathrm{x}$ & $x$ & 2 & 4 & 5 & $\mathrm{p}$ & & $\mathrm{x}$ & & & \\
\hline & & & & & & & & & & & \\
\hline Populus tremula & 3 & 2 & 3 & 4 & 4 & $\mathrm{p}$ & & $\mathrm{x}$ & $x$ & & \\
\hline Salix herbacea & 4 & 2 & 2 & 5 & 4 & $\mathrm{~h}$ & & $x$ & $x$ & & \\
\hline Salix retusa & 3 & 3 & 3 & 5 & 3 & wc & & $x$ & $x$ & $x$ & \\
\hline Salix serpyllifolia & 2 & 4 & 2 & 5 & 3 & wc & & $\mathrm{x}$ & $x$ & $x$ & \\
\hline Rhododendron ferrugineum & 3 & 2 & 2 & 3 & 4 & en & & $\mathrm{x}$ & $\mathrm{x}$ & & \\
\hline Calluna vulgaris & 3 & 1 & 1 & 3 & 4 & wc & & $x$ & $x$ & & \\
\hline Vaccinium myrtillus & 3 & 1 & 2 & 2 & 4 & wc & & $x$ & $\mathrm{x}$ & & \\
\hline Vaccinium gaultherioides & 3 & 1 & 2 & 3 & 4 & wc & & $x$ & $x$ & & \\
\hline Vaccinium vitis-idaea & 3 & 2 & 2 & 3 & 4 & WC & & $x$ & $x$ & & \\
\hline Empetrum nigrum s.l. & 1 & 2 & 2 & 4 & 4 & wc & & $x$ & $x$ & & \\
\hline Juniperus communis ssp. nana & 2 & 2 & 2 & 4 & 3 & en & & $x$ & $x$ & & \\
\hline Adenostyles leucophylla & 4 & 2 & 2 & 5 & 2 & $\mathrm{~h}$ & & & $x$ & & \\
\hline Dryopteris filix-mas & 3 & 3 & 3 & 2 & 4 & $\mathrm{~h}$ & & & $x$ & & \\
\hline Dryopteris dilatata & 4 & 2 & 3 & 2 & 4 & $\mathrm{~h}$ & & & $\mathrm{x}$ & & \\
\hline Athyrium filix-femina & 3 & 2 & 3 & 2 & 4 & $\mathrm{~h}$ & & & $x$ & & \\
\hline Athyrium distentifolium & 3 & 2 & 3 & 2 & 3 & $\mathrm{~h}$ & & & $x$ & & \\
\hline Gymnocarpium dryopteris & 3 & 2 & 3 & 2 & 3 & $\mathrm{~g}$ & & & $x$ & & \\
\hline Cystopteris fragilis & 3 & 4 & 2 & 3 & 1 & $\frac{y}{h}$ & & & 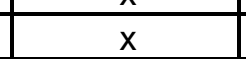 & $x$ & \\
\hline Polystichum lonchitis & 3 & 4 & 3 & 3 & 2 & $\mathrm{~h}$ & & & $\mathrm{x}$ & & \\
\hline & & & & & & & & & & & \\
\hline Sempervivum arachnoideum & 1 & 2 & 1 & 5 & 1 & $\mathrm{C}$ & & $x$ & & $x$ & \\
\hline Sempervivum montanum & 2 & 2 & 1 & 4 & 3 & $\mathrm{C}$ & & $x$ & & $x$ & \\
\hline Sempervivum tectorum ssp. alpin & 1 & 3 & 2 & 5 & 3 & $\mathrm{C}$ & & $\mathrm{x}$ & & $\mathrm{x}$ & \\
\hline Arabis alpina s.l. & 3 & 5 & 2 & 4 & 2 & c & & $x$ & & $x$ & \\
\hline Silene rupestris & 2 & 2 & 2 & 4 & 3 & $\bar{h}$ & & & & $\bar{x}$ & \\
\hline Veronica fruticans & 2 & 3 & 2 & 4 & 3 & wc & & $x$ & & $x$ & \\
\hline Agrostis rupestris & 2 & 2 & 2 & 5 & 4 & $\mathrm{~h}$ & & & & $x$ & \\
\hline & & & & & & & & & & & \\
\hline Pinguicula leptoceras & $4 w$ & 3 & 2 & 4 & 5 & $\mathrm{cp}$ & & & & & $x$ \\
\hline Pinguicula alpina & $4 w$ & 4 & 2 & 4 & 5 & $\mathrm{cp}$ & & & & & $x$ \\
\hline Eriophorum vaginatum & $4 w$ & 1 & 1 & 4 & 5 & $\mathrm{~h}$ & & & & & $x$ \\
\hline Eriophorum angustifolium & $5 w$ & 2 & 2 & 5 & 5 & $\mathrm{~g}$ & & & & & $\mathrm{x}$ \\
\hline Trichophorum caespitosum & $4 w$ & 2 & 2 & 4 & 5 & $\mathrm{~h}$ & & & & & $x$ \\
\hline Carex spec. & - & - & - & - & - & $\mathrm{h}$ & & & & & $x$ \\
\hline Hydrurus spec.(green algae) & - & - & - & - & - & $a$ & & & & & $x$ \\
\hline Stereocaulon cf. dactylophyllum & - & - & - & - & - & 1 & $x$ & $x$ & & & \\
\hline
\end{tabular}

Ecological indicator values: $F=$ humidity value, $R=$ reaction value, $N=$ nutrient value, $L=$ light value, $D=$ dispersion value

Life form: $p=$ deciduous phanerophyte, $e p=$ evergreen phanerophyte, $n=$ deciduous nanophanerophyte, en=evergreen nanophanerophyte

$\mathrm{c}=$ herbaceous chamaephyte, $\mathrm{wc}=$ woody chamaephyte, $\mathrm{h}=$ hemicryptophyte, $\mathrm{g}=$ =oophyte, $\mathrm{cp}=$ carnivorous plant, $\mathrm{a}=$ =algae, $\mathrm{l}=$ lichen

Grain sizes: $1=0.002-0.2 \mathrm{~mm}, 2=>0.2-20.0 \mathrm{~mm}, 3=>20.0->63.0 \mathrm{~mm}$

Typical pioneer plants are in bold 
Table 2. Selected chemical and physical properties of 11 typical soil profiles in the pro-glacial area

\begin{tabular}{|c|c|c|c|c|c|c|c|c|c|c|}
\hline Site/Soil & $\begin{array}{c}\text { Soil age } \\
\text { (y) }\end{array}$ & Horizons & $\begin{array}{l}\text { Depth } \\
(\mathrm{cm})\end{array}$ & $\begin{array}{l}\text { Bulk density } \\
\qquad\left(\mathrm{g} \mathrm{cm}^{-3}\right)\end{array}$ & $\begin{array}{c}\text { Skeleton }^{1)} \\
\text { (w.-\%) }\end{array}$ & $\begin{array}{l}\text { Sand }^{2)} \\
(\%)\end{array}$ & $\begin{array}{l}\text { Silt }^{2)} \\
(\%)\end{array}$ & $\begin{array}{l}\text { Clay }^{2)} \\
(\%)\end{array}$ & $\begin{array}{c}\mathrm{pH} \\
\left(\mathrm{CaCl}_{2}\right)\end{array}$ & $\begin{array}{l}\text { Org. C } \\
\left.\left(g^{-1}\right)^{-1}\right)\end{array}$ \\
\hline \multicolumn{11}{|c|}{ A/Humi-Skeletic Leptosol (Ranker) } \\
\hline & 140 & A & $0-7$ & 1.4 & 65 & 77 & 19 & 4 & 5.2 & 34.3 \\
\hline & & $(B w) A$ & $7-25$ & 1.9 & 59 & 78 & 19 & 3 & 5.1 & 3.7 \\
\hline & & C & $>25$ & 1.9 & 64 & 78 & 19 & 3 & 5.4 & 2.5 \\
\hline \multicolumn{11}{|c|}{ 1/Skeletic Fluvisol } \\
\hline & 140 & (C)A1 & $0-2$ & 1.0 & 11 & 55 & 36 & 9 & 4.8 & 16.4 \\
\hline & & (C)A1 & $2-8$ & 1.0 & 11 & 55 & 36 & 9 & 4.8 & 16.4 \\
\hline & & $2 \mathrm{C}$ & $8-14$ & 1.3 & 19 & 49 & 42 & 9 & 4.9 & 8.4 \\
\hline & & $3 C$ & $14-23$ & & 70 & n.m. & n.m. & n.m. & 4.9 & 8.4 \\
\hline \multicolumn{11}{|c|}{ 2/Humi-Skeletic Leptosol } \\
\hline & 120 & $A$ & $0-3$ & 1.5 & 40 & 75 & 21 & 4 & 5.5 & 176.1 \\
\hline & & $\mathrm{C}$ & $3-13$ & 1.5 & 65 & 70 & 27 & 3 & 4.9 & 16.7 \\
\hline \multicolumn{11}{|c|}{ 3/Skeletic Leptosol } \\
\hline & 100 & $A$ & $0-2$ & 1.5 & 40 & 67 & 26 & 7 & n.m. & 6.9 \\
\hline & & $\mathrm{C}$ & $2-26$ & 1.5 & 70 & 68 & 28 & 4 & 5 & 1.7 \\
\hline \multicolumn{11}{|c|}{ 4/Skeletic Leptosol } \\
\hline & 80 & $A$ & $0-2$ & 1.1 & 15 & n.m. & n.m. & n.m. & n.m. & 5.2 \\
\hline & & $A C$ & $2-6$ & 1.5 & 70 & 85 & 12 & 3 & 4.5 & 5.2 \\
\hline & & (B)C & $6-8$ & 1.5 & 75 & 85 & 12 & 3 & 4.5 & 5.2 \\
\hline & & $\mathrm{C}$ & 8-14 & 1.4 & 75 & 84 & 14 & 2 & 4.8 & 1.7 \\
\hline \multicolumn{11}{|c|}{ 5/Skeletic Leptosol } \\
\hline & 70 & $A$ & $0-3$ & & 40 & 82 & 14 & 4 & n.m. & n.m. \\
\hline & & $\mathrm{C}$ & $3-22$ & 1.3 & 68 & 73 & 22 & 5 & 4.5 & 4.4 \\
\hline
\end{tabular}




\begin{tabular}{lccccccccccc} 
& 60 & CA & $0-12$ & 1.5 & 55 & 85 & 13 & 2 & 5.1 & 6 \\
7/Skeletic Leptosol & & & AC & $0-6$ & 1.5 & 53 & 92 & 6 & 2 & 5.2 & 1.9 \\
8/Skeletic Leptosol & 30 & C & $6-25$ & 1.4 & 70 & 83 & 14 & 3 & 5.4 & 0.7 \\
9/Skeletic Leptosol & 30 & (A)C & $0-15$ & 1.6 & 66 & 82 & 17 & 1 & 5.7 & 2 \\
10/Lithic Leptosol & 20 & (A)C & $0-18$ & 1.8 & 77 & n.m. & n.m. & n.m. & 5.7 & 2 \\
& 10 & C & $0-9$ & 1.7 & 75 & 75 & 22 & 3 & 5.8 & 0.9 \\
\hline
\end{tabular}

1) soil skeleton $=$ diameter of the material $>2 \mathrm{~mm}$.

2) size fractions: sand $(2000-63 \mu \mathrm{m})$, silt $(<63-2 \mu \mathrm{m})$, clay $(<2 \mu \mathrm{m})$

n.m. = not measured 
Table 3. Soil moisture of four monitored sites (two different soil types) in the pro-glacial area Morteratsch

\begin{tabular}{cccc}
\hline $\begin{array}{c}\text { Soil type } \\
\text { (FAO, 1998) }\end{array}$ & $\begin{array}{c}\text { Soil age } \\
(\mathrm{y})\end{array}$ & $\begin{array}{c}\text { Mean moisture } \\
(\mathrm{hPa} ; \pm \mathrm{SD})\end{array}$ & $\begin{array}{c}\text { Moisture } \\
(\mathrm{max} \mathrm{hPa})\end{array}$ \\
\hline Humi-Skeletic Leptosol & 108 & $243( \pm 113)$ & 440 \\
& 98 & $176( \pm 35)$ & 210 \\
Skeletic/Lithic Leptosol & 48 & $249( \pm 132)$ & 425 \\
& 58 & $158( \pm 21)$ & 180 \\
\hline
\end{tabular}


Table 4. Comparison of vegetation with soil data of the glacier foreland Morteratsch

\begin{tabular}{l}
\hline Vegetation data (see vegetation \\
\hline man) \\
\hline Mainly moss pioneers \\
Rhacomitrium canescens, Pohlia spec., \\
Saxifraga aizoides \\
Oxyrietum digynae \\
AC Oxyria digyna, Linaria alpina, Saxifraga \\
bryoides, Cerastium uniflorum, Cardamine \\
resedifolia, Poa alpina, P. nemoralis \\
\\
Epilobietum fleischeri \\
AC Epilobium fleischeri, AC Hieracium \\
staticifolium, AS Geum reptans, Rumex \\
scutatus, Trifolium pallescens, T. pratense \\
ssp. nivale, Achillea moschata, Saxifraga \\
bryoides, Cerastium uniflorum, Cardamine \\
resedifolia, Poa alpina, P. nemoralis, Lotus \\
alpinus, Larix decidua, Myricaria \\
germanica, Alnus viridis, Salix spec., \\
Rhododendron ferrugineum, Stereocaulon \\
Boulder vegetation \\
Adenostyles leucophylla, Rumex scutatus, \\
Dryopteris spec., Athyrium spec., \\
Gymnocarpium dryopteris, Polystichum \\
lonchitis \\
\hline
\end{tabular}

Alnetum viridis, Alnus viridis stands, Adenostylion, Salix shrubs, grass

AC Alnus viridis and tall perennial herbs, Salix spec., Poa spec., Deschampsia caespitosa, Avenella flexuosa, Nardus stricta, Festuca spec., Phleum rhaeticum, Anthoxanthum alpinum, Calamagrostis

\section{Larici-Pinetum cembrae (climax} veqetation)

AC Pinus cembra, AC Larix decidua, AllC Rhododendron ferrugineum, Luzula sylvatica, OC Calamagrostis villosa, AS Vaccinium spec., Clematis alpina, Homogyne alpina, Oxalis acetosella,

\section{Alnetum viridis, Salix shrubs,} Epilobietum fleischeri, flood vegetation AC Alnus viridis, Salix spec., Adenostyles leucophylla, AC Epilobium fleischeri, AC Hieracium staticifolium

Soil data (see soil map)

\section{Skeletic / Lithic Leptosol or 'no soil'}

grain size: clay/ silt - fine sand, $0.002-0.2$ $\mathrm{mm}$

grain size: clay / silt - fine sand $0.002-0.2$ $\mathrm{mm}$, coarse sand-gravel $>0.2-20.00 \mathrm{~mm}$ weakly developed soil with some humus in small pockets

coarse gravel-boulders $>20.00->63.0 \mathrm{~mm}$

\section{Humi-Skeletic Leptosol}

weakly developed soil with continuous humus layer

\section{Dystric Cambisol}

relatively stable surface and better developed soil

\section{Endoskeletic Fluvisol}

alluvial soil, continuous erosion and flood deposition 
Key of symbols: $\mathrm{AC}=$ Association character species, $\mathrm{AllC}=\mathrm{Alliance}$ character species, $\mathrm{OC}=\mathrm{Order}$ character species, AS=Accessory species 
Table 5. Absolute and relative distribution of vegetation units within the pro-glacial area with respect to the soil types

\begin{tabular}{|c|c|c|c|c|c|c|c|c|c|c|c|c|c|}
\hline \multirow[b]{2}{*}{ Vegetation } & \multicolumn{6}{|c|}{ Vegetation distribution on soil types: Absolute area } & \multicolumn{7}{|c|}{ Vegetation distribution on soil types: Relative area } \\
\hline & $\begin{array}{l}\text { Skeletic/ } \\
\text { Lithic } \\
\text { Leptosol } \\
\left(\mathrm{m}^{2}\right)\end{array}$ & $\begin{array}{l}\text { Humi- } \\
\text { Skeletic } \\
\text { Leptosol } \\
\left(\mathrm{m}^{2}\right)\end{array}$ & $\begin{array}{l}\text { Endo- } \\
\text { skeletic } \\
\text { Fluvisol } \\
\left(\mathrm{m}^{2}\right)\end{array}$ & $\begin{array}{l}\text { Dystric } \\
\text { Cambisol } \\
\left(\mathrm{m}^{2}\right)\end{array}$ & $\begin{array}{c}\text { Gleyic } \\
\text { Cambisol } \\
\left(\mathrm{m}^{2}\right)\end{array}$ & $\begin{array}{l}\text { No soil } \\
\left(\mathrm{m}^{2}\right)\end{array}$ & $\begin{array}{l}\text { Skeletic/ } \\
\text { Lithic } \\
\text { Leptosol } \\
\% \\
\end{array}$ & $\begin{array}{c}\text { Humi- } \\
\text { Skeletic } \\
\text { Leptosol } \\
\% \\
\end{array}$ & $\begin{array}{l}\text { Endo- } \\
\text { skeletic } \\
\text { Fluvisol } \\
\quad \%\end{array}$ & $\begin{array}{c}\text { Dystric } \\
\text { Cambisol } \\
\\
\%\end{array}$ & $\begin{array}{c}\text { Gleyic } \\
\text { Cambisol } \\
\\
\%\end{array}$ & $\begin{array}{l}\text { No } \\
\text { soil } \\
\%\end{array}$ & $\begin{array}{l}\text { Sum } \\
\%\end{array}$ \\
\hline $\begin{array}{l}\text { Larch-Swiss stone } \\
\text { pine forest (Larici- } \\
\text { Pinetum cembrae), } \\
\text { partially Swiss stone } \\
\text { pine forest }\end{array}$ & 4247 & 3897 & 395 & 596 & 0 & 10005 & 22 & 20 & 2 & 3 & 0 & 52 & 100 \\
\hline $\begin{array}{l}\text { Dwarf shrub heath } \\
\text { (Rhododendro- } \\
\text { Vaccinietum, } \\
\text { Empetro-Vaccinietum, } \\
\text { Junipero- } \\
\text { Arctostaphyletum) }\end{array}$ & 269 & 0 & 0 & 0 & 0 & 0 & 100 & 0 & 0 & 0 & 0 & 0 & 100 \\
\hline $\begin{array}{l}\text { Green alder scrub } \\
\text { (Alnetum viridis) }\end{array}$ & 70120 & 109073 & 1788 & 2175 & 0 & 25531 & 34 & 52 & 1 & 1 & 0 & 12 & 100 \\
\hline $\begin{array}{l}\text { Grass heath on moist } \\
\text { soils (grass species } \\
\text { e.g. Festuca violacea, } \\
\text { Calamagrostis villosa, } \\
\text { Phleum rhaeticum, } \\
\text { Poa alpina) }\end{array}$ & 6408 & 14950 & 773 & 1791 & 0 & 4660 & 22 & 52 & 3 & 6 & 0 & 16 & 100 \\
\hline $\begin{array}{l}\text { Pioneer grass } \\
\text { communities }\end{array}$ & 58858 & 48402 & 217 & 1322 & 256 & 26048 & 44 & 36 & 0 & 1 & 0 & 19 & 100 \\
\hline $\begin{array}{l}\text { Epilobietum fleischeri } \\
\text { with single willow } \\
\text { shrubs and alpenrose }\end{array}$ & 212542 & 88809 & 8873 & 993 & 191 & 350398 & 32 & 13 & 1 & 0 & 0 & 53 & 100 \\
\hline $\begin{array}{l}\text { Oxyrietum digynae } \\
\text { with Myricaria } \\
\text { germanica, Saxifraga } \\
\text { aizoides, Linaria }\end{array}$ & 9310 & & & & & 7839 & 54 & 0 & 0 & 0 & 0 & 46 & 100 \\
\hline
\end{tabular}


alpina and moss

cushions

(Rhacomitrium spec.,

Pohlia spec.)

\section{Boulder plant}

18148

24619

0

100

0

38797

mmunities, partially

Epilobietum fleischeri,

Adenostyles

leucophylla and

several fern species

Rock vegetation (e.g

2003

Agrostis rupestris,

4435

0

0

70409

0

48

100

Silene rupestris,

Sempervivum

arachnoideum) 
Table 6. Relative distribution of the vegetation types in respect to the grain sizes (soil)

\begin{tabular}{|c|c|c|c|c|c|c|c|c|c|c|}
\hline Vegetation types / Grain sizes & $\begin{array}{l}\text { Skeleton } \\
\text { free } \\
(<5 \text { v.- } \%)\end{array}$ & $\begin{array}{l}\text { Skeleton } \\
\text { present* } \\
(5-10 \text { v.-\%) }\end{array}$ & $\begin{array}{c}\text { Weakly } \\
\text { gravely* } \\
(10-20 \text { v.-\%) }\end{array}$ & $\begin{array}{c}\text { Stony } \\
(10-20 \text { v. }-\%)\end{array}$ & $\begin{array}{c}\text { Strongly } \\
\text { gravely } \\
(20-30 \text { v.- } \%)\end{array}$ & $\begin{array}{l}\text { Strongly } \\
\text { stony } \\
(20-30 \text { v.-\%) }\end{array}$ & $\begin{array}{c}\text { rich in } \\
\text { gravels } \\
(30-50 \text { v.-\%) }\end{array}$ & $\begin{array}{l}\text { rich in } \\
\text { stones } \\
(30-50 \text { v.-\%) }\end{array}$ & $\begin{array}{c}\text { Debris, } \\
\text { boulders } \\
(>50 \text { v. }-\%)\end{array}$ & Sum \\
\hline $\begin{array}{l}\text { Oxyrietum digynae with Myricaria } \\
\text { germanica, Saxifraga aizoides, } \\
\text { Linaria alpina and moss cushions } \\
\text { (Rhacomitrium spec., Pohlia } \\
\text { spec.) }\end{array}$ & $0.0 \%$ & $0.0 \%$ & $0.0 \%$ & $0.0 \%$ & $100.0 \%$ & $0.0 \%$ & $0.0 \%$ & $0.0 \%$ & $0.0 \%$ & $100 \%$ \\
\hline $\begin{array}{l}\text { Epilobietum fleischeri with single } \\
\text { willow shrubs and alpenrose }\end{array}$ & $2.4 \%$ & $0.6 \%$ & $0.7 \%$ & $3.9 \%$ & $24.6 \%$ & $8.6 \%$ & $13.1 \%$ & $42.2 \%$ & $4.0 \%$ & $100 \%$ \\
\hline $\begin{array}{l}\text { Pioneer grass communities. } \\
\text { Outside of the pro-glacial area } \\
\text { grass heath (Geo montani- } \\
\text { Nardetum and Poion alpinae, } \\
\text { above ca. } 2400 \text { m Caricetum } \\
\text { curvulae) }\end{array}$ & $6.5 \%$ & $1.2 \%$ & $4.8 \%$ & $7.8 \%$ & $38.6 \%$ & $9.9 \%$ & $10.7 \%$ & $17.0 \%$ & $3.6 \%$ & $100 \%$ \\
\hline $\begin{array}{l}\text { Grass heath on moist soils } \\
\text { (Dystric Cambisols, grass } \\
\text { species e.g. Festuca violacea, } \\
\text { Calamagrostis villosa, Phleum } \\
\text { rhaeticum, Poa alpina) }\end{array}$ & $3.2 \%$ & $2.8 \%$ & $4.8 \%$ & $42.0 \%$ & $18.9 \%$ & $5.7 \%$ & $0.2 \%$ & $22.5 \%$ & $0.0 \%$ & $100 \%$ \\
\hline $\begin{array}{l}\text { Green alder scrub (Alnetum } \\
\text { viridis) }\end{array}$ & $1.5 \%$ & $0.4 \%$ & $3.0 \%$ & $16.6 \%$ & $31.2 \%$ & $4.7 \%$ & $3.1 \%$ & $38.9 \%$ & $0.6 \%$ & $100 \%$ \\
\hline $\begin{array}{l}\text { Boulder plant communities, } \\
\text { partially Epilobietum fleischeri, } \\
\text { Adenostyles leucophylla and } \\
\text { several fern species }\end{array}$ & $0.0 \%$ & $0.0 \%$ & $0.6 \%$ & $11.9 \%$ & $29.8 \%$ & $26.2 \%$ & $0.7 \%$ & $30.7 \%$ & $0.0 \%$ & $100 \%$ \\
\hline $\begin{array}{l}\text { Rock vegetation (e.g. Agrostis } \\
\text { rupestris, Silene rupestris, } \\
\text { Sempervivum arachnoideum) }\end{array}$ & $21.2 \%$ & $0.0 \%$ & $7.7 \%$ & $3.1 \%$ & $13.0 \%$ & $46.8 \%$ & $8.0 \%$ & $0.2 \%$ & $0.0 \%$ & $100 \%$ \\
\hline $\begin{array}{l}\text { Larch-Swiss stone pine forest } \\
\text { (Larici-Pinetum cembrae), }\end{array}$ & $4.3 \%$ & $6.5 \%$ & $13.4 \%$ & $12.1 \%$ & $17.2 \%$ & $23.8 \%$ & $0.0 \%$ & $22.7 \%$ & $0.0 \%$ & $100 \%$ \\
\hline
\end{tabular}


partially Swiss stone pine forest

*soil skeleton: material $>2 \mathrm{~mm}$ in diameter; gravely: predominantly material $<5 \mathrm{~cm}$ in diameter; stony: predominantly material $>5 \mathrm{~cm}$ in diameter 